\title{
Feasting on Wild Boar in the Early Neolithic. Evidence from an 11,400-year-old Placed Deposit at Tappeh Asiab, Central Zagros
}

\author{
Pernille Bangsgaard, Lisa Yeomans, Hojjat Darabi, \\ Kristian Murphy Gregersen, Jesper Olsen, Tobias Richter \& \\ Peder Mortensen
}

\begin{abstract}
The contents of a pit located in the centre of a large communal structure at Asiab in the central Zagros mountains provides rare evidence for ritual food practices during the Early Neolithic ( 9660-9300 cal. BC). This pit contained the skulls of at least 19 wild boars carefully placed inside and subsequently sealed. Antler from red deer and the skull of a brown bear were also concealed within the pit. The boars included both male and female animals varying in age and some of the larger canines were deliberately removed. Such a unique collection of remains is unlikely to be the result of day-to-day activities; instead, this represents a group of ritually interred bones. This new evidence strengthens views that activities reinforcing social cohesion were important as human society was approaching a juncture leading towards agricultural subsistence strategies.
\end{abstract}

\section{Introduction}

In recent years feasting has become an increasingly central concern for archaeologists working on the transition from hunting and gathering to early agricultural societies in southwest Asia (Dietrich et al. 2012; Goring-Morris \& Horwitz 2007; Munro \& Grosman 2010; Twiss 2008). Feasts and ceremonies centred on the display and consumption of food are considered as powerful social strategies for forming alliances, aggrandizing power and gaining influence, or alleviating dissonance within growing early sedentary communities. Some have related feasting to the emergence of socially complex and hierarchical social systems during the Late Epipalaeolithic and Early Neolithic ${ }^{1}$ (Hayden 1990; 1995), while others have highlighted feasting as a levelling mechanism that enforced food sharing (Kuijt 2010; Zeder 2011). The need to form alliances and maintain influence may have fuelled demand for luxury food items and products, such as beer or highly valued meats, which in turn has been seen as a potential impetus for people to cultivate cereals and domesticate animals. Other scholars have advocated that the importance of such feasting events lay in maintaining social cohesion (Kuijt 2010; Zeder 2011). However, archaeological evidence for feasting is often not clear-cut (Rowley-Conwy 2018; Twiss 2008). While some case studies provide strong evidence for specific feasting events at some sites (e.g. Hilazon Tachtit: Munro \& Grosman 2010; Kfar HaHoresh: Horwitz \& Goring-Morris 2004), the evidence for feasting at other locales is more circumspect. In many cases, not all the criteria for the identification of feasts in archaeological contexts, helpfully put together by Twiss (2008) and Helwing (2003), are fulfilled. While it is important to guard against en vogue interpretations of the archaeological record, the evidence for feasts from the Levant and Anatolia has certainly been increasing in recent years. Sites in the eastern Fertile Crescent with more solid evidence of feasts include Zawi Chemi and Hallam Çemi (Solecki 
1977; 1981; Zeder \& Spitzer 2016), but an absence of evidence in the easternmost part of the Fertile Crescent has been noted (Bernbeck 2004). Matthews et al. (2013) have questioned whether this lack of elaborate cultic or ritual activities is a valid conclusion, or merely reflects bias in the frequency of research. In comparison to the intense research efforts that have been devoted to investigating Late Epipalaeolithic and Early Neolithic sites in the Levant and Anatolia, the eastern wing of the Fertile Crescent, specifically the Zagros Mountains in modern-day Iran, has been less frequently and thoroughly investigated. This has started to change in recent years due to the efforts of Iranian archaeologists (Darabi et al. 2011; 2013; Moradi et al. 2016) and some joint projects between Iranian and foreign archaeological teams (Matthews et al. 2013; Riehl 2013), but we still know little about the environmental, social and economic conditions of Late Epipalaeolithic and Early Neolithic societies in this region. Were feasts and ceremonial events centred on food consumption features that also characterized the changing societal customs in the eastern part of the Fertile Crescent? If so, did feasting together with other influences play a role in putting societies on a trajectory towards resource management and intensification? What can we learn about the cultural similarities evident in feasting practices and food-related ceremonies between the different parts of the Fertile Crescent?

Here we report on an unusual placed deposit of wild boar skulls from the recently re-excavated Early Neolithic site of Asiab, situated in the Kermanshah province in the central Zagros Mountains of Iran (Fig. 1). Asiab was first excavated by Bruce Howe, as part of Robert Braidwood's research into the prehistory of Iranian Kurdistan in 1959-60. Recent work revealed a pit replete with numerous wild boar skulls, suggesting the occurrence of a feasting event. In discussing this evidence, we reflect on the difficulties associated with identifying feasting events in archaeological contexts in southwest Asia and discuss the implications of this evidence for our understanding of the articulation of Early Neolithic societies in the central Zagros.

\section{Recovery context}

Asiab was initially excavated as a part of the Iranian Prehistoric Project (IPP) based in the area around Kermanshah, alongside excavations at the Palaeolithic and Neolithic sites of Warwarsi and Sarab in 1959 and 1960 (Braidwood 1960; 1961; Braidwood et al. 1961). The most detailed report on these excavations is given by Howe (1983), describing the site of Asiab as covering an area of 20,000 sq. $\mathrm{m}$ of which 130 sq. $\mathrm{m}$ were excavated in a series of trenches. Only a single large trench, measuring $6 \times 8 \mathrm{~m}$, was excavated down to the underlying natural soil, $2.5-3 \mathrm{~m}$ below the surface. Finds were described as a 'chaotic jumble' of worked flint, other stone, animal bones, ash, freshwater clams and burnt rock. At the base of the trench, a quarter of a large pit or semi-subterranean structure was dug into the natural geology. Several pits and two human interments were found in the interior of the feature. One of the burials was laid in an extended position and the other in a crouched position and both appear to have been sprinkled with ochre. A large number of animal bones were recovered and a number of features cutting the infill of the structure are described as fire-pits, cooking-pits and hearths. It remains uncertain if these were of an Early Neolithic date, as Bronze Age pottery was still present just above the base of the cut. In 1977 Sándor Bökönyi published an analysis of the faunal remains from various excavations around Kermanshah, including Asiab. Although details about the recovery context are minimal, a number of Suidae remains were discussed. Of note is a wild pig skull described as an 'approximately 18 month old wild sow' (Bökönyi 1977, fig. 24).

In 2016 an Iranian-Danish team from the University of Copenhagen and Razi University returned to Asiab (Darabi et al. 2018). The excavation located the original $6 \times 8 \mathrm{~m}$ area and re-exposed the large cut (Fig. 2). A second area was opened adjacent to Howe's old excavation area to the east, where the continuation of the large cut that Howe had identified was found. Based on the presence of a floor in the new trench as well as a plaster bench around the edge of the cut, it was clear that the feature represented a large semi-subterranean structure. Deposits were heavily disturbed by animal burrows, although some midden deposits that infilled the structure remained in situ. The size of the structure (approximately $10 \mathrm{~m}$ in diameter) indicates that it may have been a communal building, yet no other structures were found in the vicinity (Darabi et al. 2018). Only the deep cut of the one large semi-subterranean structure survived erosion, subsequent ploughing and other activities. Although little is therefore known about the original appearance of the settlement at Asiab, the site appears to share some similarities with broadly contemporary sites in the eastern Fertile Crescent, such as Hallan Çemi (Rosenberg \& Davis 1992; Rosenberg et al. 1995; 1998). Peasnall (2000) grouped these sites under the cultural label 


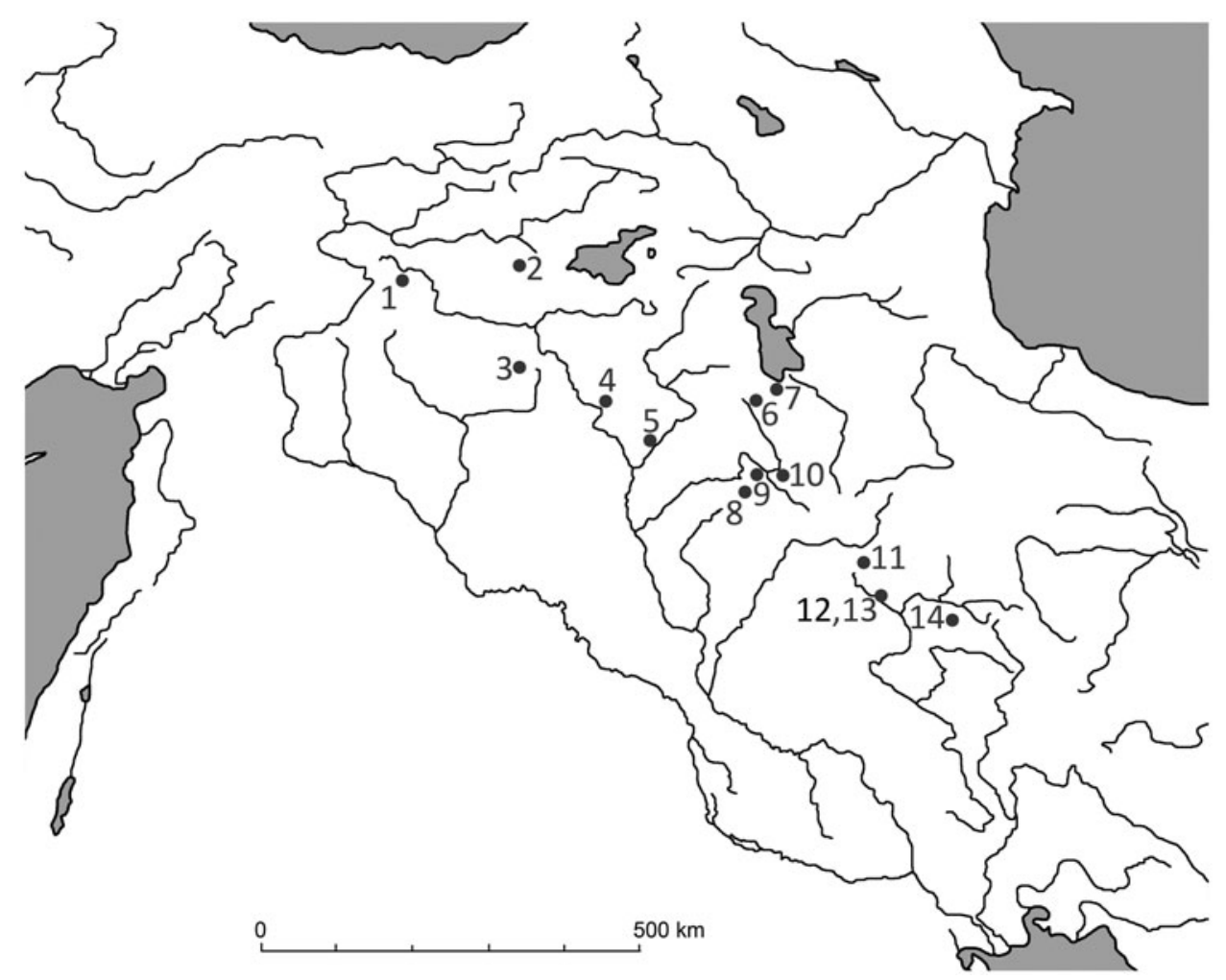

Figure 1. Distribution of wild boar and locations of sites mentioned in the text. (1) Çayönü; (2) Hallan Çemi; (3-Tell Leilan; (4) Nemrik 9; (5) M'lefaat; (6) Banahilk; (7) Hajji Firuz; (8) Jarmo; (9) Karim Shahir; (10) Palegawa; (11) Warwarsi; (12) Asiab; (13) Sarab; (14) Ganj Dareh.

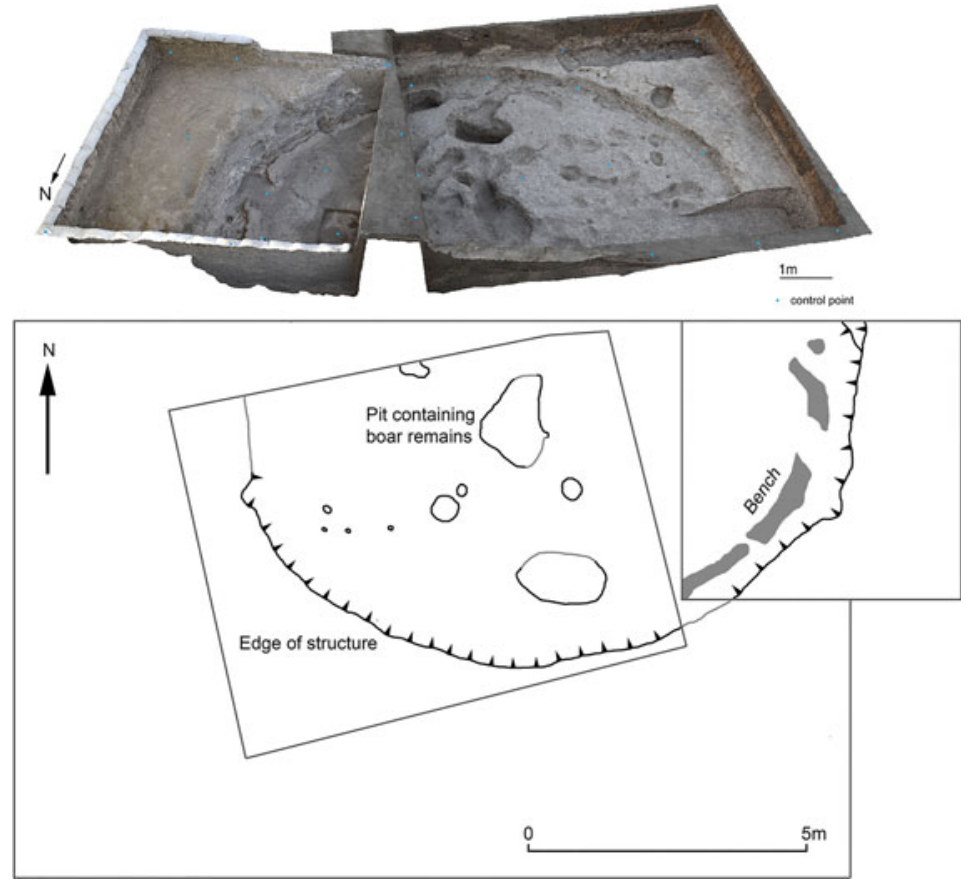

Figure 2. Plan and photogrammetry model of the structure at Asiab showing the part of the structure exposed by Braidwood's team to the west and the new excavation trench to the east. 

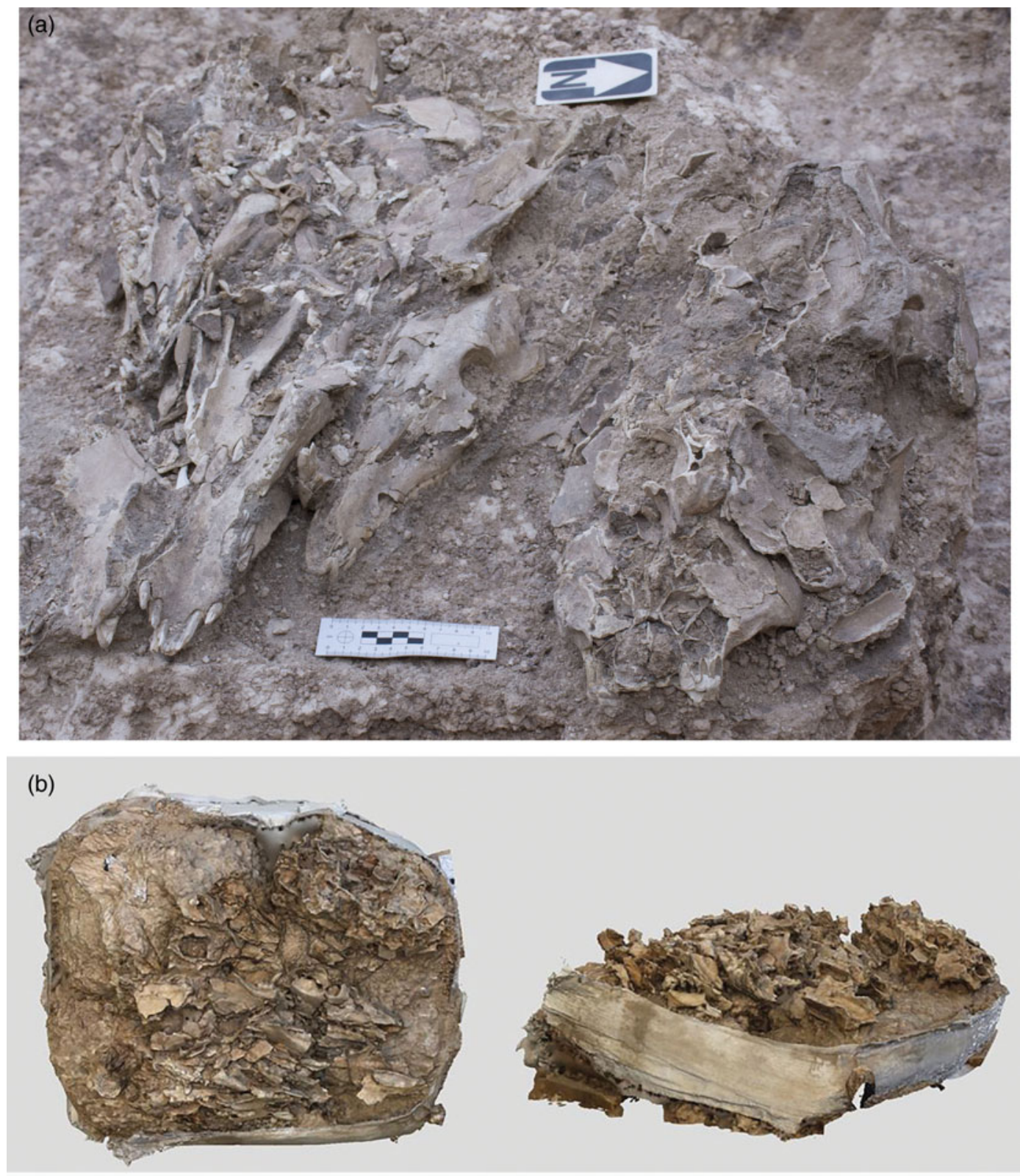

Figure 3. Stages in the excavation of the pit. (a) Exposed contents of the pit prior to encasing in plaster; (b) 3D photogrammetry model created as the contents of the pit were exposed during conservation work.

'Round House Horizon' with a geographical range along the Taurus-Zagros Arc. Going on lithic typology, the site can be grouped under the Pre- or Early M'lefaatian lithic industry of the tenth and mid ninth millennium BC (Darabi 2015; Kozlowski 1999; Nishiaki \& Darabi 2018).

Peasnall (2000) suggested that during the Late Round House Horizon, settlements incorporated a large open area or plaza forming a focal point for food production and ritual activities. The clearest example of this was two communal structures at
Hallan Çemi in the later phase of occupation. Evidence for large-scale feasting in these structures included a higher proportion of large game, articulated portion of limbs. Different species of avifaunal remains including larger birds and the wing and feet of raptors as well as a complete aurochs skull in one building and three wild sheep in the other, with red deer antler interpreted as relating to ritual accoutrements (Zeder \& Spitzer 2016).

In the original excavation trench at Asiab and roughly in the centre of the structure a large pit 


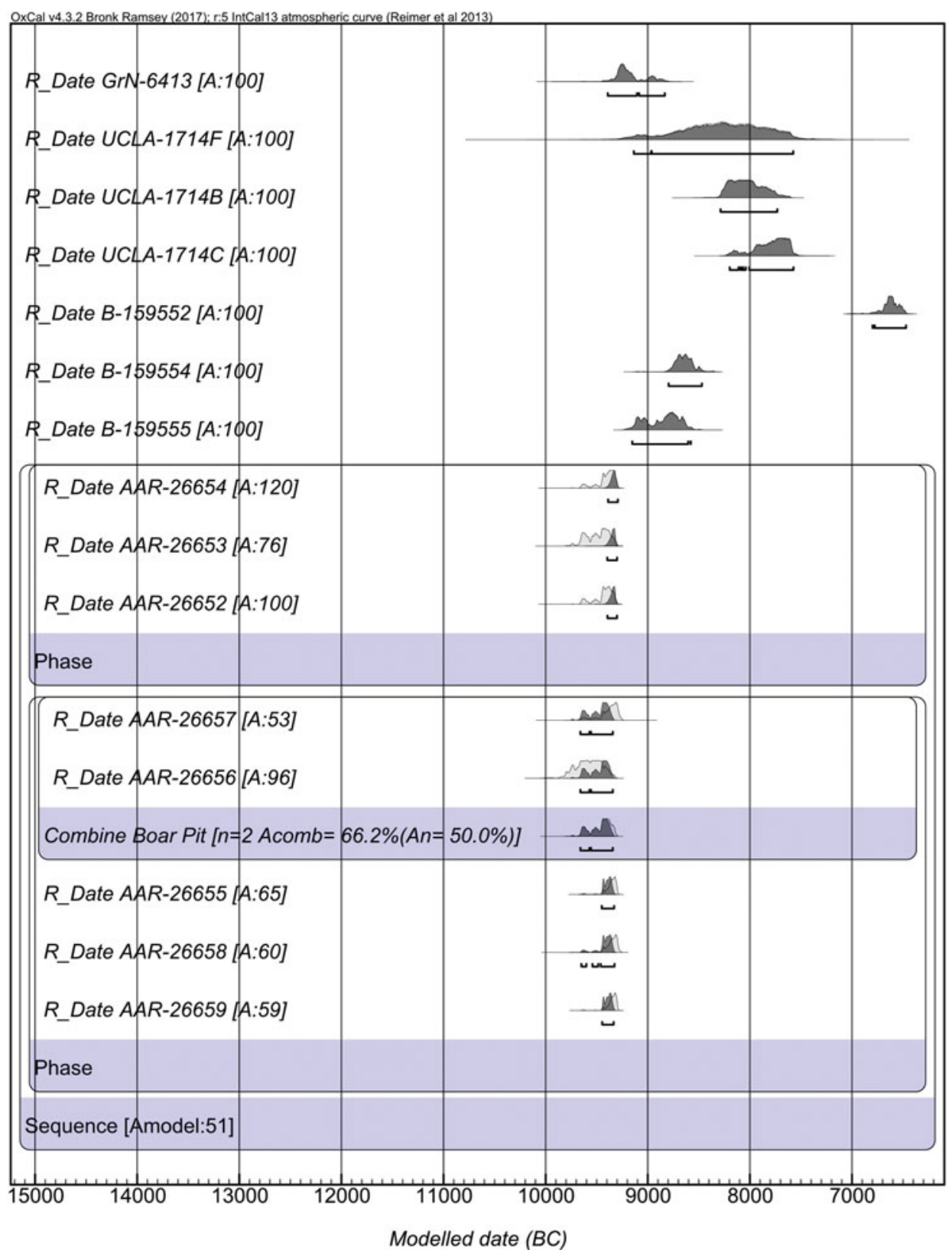

Figure 4. OxCal plot of the new and previous radiocarbon AMS dates from Asiab. All AAR dates were recently analysed from samples obtained during the new excavations. All other dates are from Zeder (2008) and Howe (1983). The AAR dates were sub-divided into two phases for Bayesian modelling. We used the Sequence function in OxCal 4.3 to model the dates. The two dates from the boar pit (AAR-26656 and AAR-26657) were combined using the Combine function in OxCal 4.3.

was discovered. This measured $1.6 \times 1 \mathrm{~m}$ with a depth of $0.3-0.4 \mathrm{~m}$ and the pit was sealed by a layer of redeposited natural soil. As the redeposited natural was identical in composition to the surrounding soil, the pit had probably gone unnoticed by Braidwood's team. Once the intentional capping soil was removed, it was clear that the pit contained a very high density of Suidae mandibles and crania, which had been arranged in an east-west direction facing east (Fig. 3). The mandibles and crania were packed tightly into the pit in separate groups with mandibles to one side and crania to the other. The close proximity of remains posed significant challenges during excavation. Time was limited and, given the density 
Table 1. Radiocarbon dates from Asiab.

\begin{tabular}{|c|c|c|c|c|c|c|c|c|c|c|c|c|}
\hline $\begin{array}{l}\text { Sample } \\
\text { lab. code }\end{array}$ & Sample ID & Context & $\begin{array}{c}\text { Material } \\
\text { dated }\end{array}$ & $\begin{array}{l}\text { Uncal. } \\
\text { date }\end{array}$ & pMC & $\begin{array}{c}\delta^{13} \mathrm{C} \\
(\mathrm{CF}-\mathrm{CN})\end{array}$ & $\begin{array}{l}\text { Carbon } \\
\text { fraction } \\
\text { (TCD) }\end{array}$ & $\begin{array}{l}\text { Nitrogen } \\
\text { fraction } \\
\text { (TCD) }\end{array}$ & $\begin{array}{c}\text { Years } \\
\text { cal. вС } \\
1 \sigma\end{array}$ & $\begin{array}{l}\text { Years } \\
\text { cal. вС } \\
2 \sigma\end{array}$ & $\begin{array}{c}\text { Modelled dates } \\
\text { years } \\
\text { cal. } \mathrm{BC} \\
1 \sigma\end{array}$ & $\begin{array}{c}\text { Modelled dates } \\
\text { years } \\
\text { cal. BC } \\
2 \sigma\end{array}$ \\
\hline \multicolumn{13}{|c|}{ Bruce Howe dates } \\
\hline GrN-6413 & $\mathrm{n} / \mathrm{a}$ & - & $\begin{array}{l}\text { Charcoal } \\
\text { (unspecified) }\end{array}$ & $9755 \pm 85$ & $\mathrm{n} / \mathrm{a}$ & $\mathrm{n} / \mathrm{a}$ & $\mathrm{n} / \mathrm{a}$ & $\mathrm{n} / \mathrm{a}$ & 9307-8945 & 9393-8835 & $9310-8944$ & $9392-8833$ \\
\hline UCLA-1714F & $\mathrm{n} / \mathrm{a}$ & - & Bone collagen & $9050 \pm 300$ & $\mathrm{n} / \mathrm{a}$ & $\mathrm{n} / \mathrm{a}$ & $\mathrm{n} / \mathrm{a}$ & $\mathrm{n} / \mathrm{a}$ & $8616-7791$ & 9142-7576 & $8618-7760$ & $9137-7576$ \\
\hline UCLA-1714B & $\mathrm{n} / \mathrm{a}$ & - & Bone collagen & $8900 \pm 100$ & $\mathrm{n} / \mathrm{a}$ & $\mathrm{n} / \mathrm{a}$ & $\mathrm{n} / \mathrm{a}$ & $\mathrm{n} / \mathrm{a}$ & $8247-7939$ & $8287-7732$ & $8247-7878$ & $8287-7732$ \\
\hline UCLA-1714C & $\mathrm{n} / \mathrm{a}$ & - & Bone collagen & $8700 \pm 100$ & $\mathrm{n} / \mathrm{a}$ & $\mathrm{n} / \mathrm{a}$ & $\mathrm{n} / \mathrm{a}$ & $\mathrm{n} / \mathrm{a}$ & 7937-7595 & $8198-7574$ & 7937-7595 & $8198-7574$ \\
\hline \multicolumn{13}{|c|}{ Zeder and Hesse dates } \\
\hline B-159552 & $\mathrm{n} / \mathrm{a}$ & - & Bone collagen & $7790 \pm 60$ & $\mathrm{n} / \mathrm{a}$ & $\mathrm{n} / \mathrm{a}$ & $\mathrm{n} / \mathrm{a}$ & $\mathrm{n} / \mathrm{a}$ & $6684-6529$ & $6798-6471$ & $6685-6528$ & $6799-6471$ \\
\hline B-159554 & $\mathrm{n} / \mathrm{a}$ & - & Bone collagen & $9370 \pm 60$ & $\mathrm{n} / \mathrm{a}$ & $\mathrm{n} / \mathrm{a}$ & $\mathrm{n} / \mathrm{a}$ & $\mathrm{n} / \mathrm{a}$ & 8723-8568 & 8795-8469 & $8722-8567$ & $8796-8471$ \\
\hline B-159555 & $\mathrm{n} / \mathrm{a}$ & - & Bone collagen & $9480 \pm 80$ & $\mathrm{n} / \mathrm{a}$ & $\mathrm{n} / \mathrm{a}$ & $\mathrm{n} / \mathrm{a}$ & $\mathrm{n} / \mathrm{a}$ & 9117-8639 & 9152-8576 & 9118-8639 & 9152-8579 \\
\hline \multicolumn{13}{|c|}{ New TCEC dates } \\
\hline AAR-26654 & 2085 & 2041 & $\begin{array}{l}\text { Wood charcoal: } \\
\text { Salicaceae }\end{array}$ & $9940 \pm 37$ & $29.01 \pm 0.14$ & $-26.42 \pm 0.11$ & $50.85 \pm 0.01$ & $1.05 \pm 0.01$ & 9443-9316 & 9652-9293 & 9357-9310 & 9389-9294 \\
\hline AAR-26653 & 2154 & 2035 & $\begin{array}{l}\text { Wood charcoal: } \\
\text { Amygdalus }\end{array}$ & $9980 \pm 39$ & $28.87 \pm 0.14$ & $-24.69 \pm 0.11$ & $59.82 \pm 0.01$ & $1.38 \pm 0.01$ & $9651-9360$ & 9670-9316 & $9365-9317$ & 9397-9301 \\
\hline AAR-26652 & 2220 & 2035 & $\begin{array}{l}\text { Wood charcoal: } \\
\text { Amygdalus }\end{array}$ & $9959 \pm 30$ & $28.94 \pm 0.11$ & $-26.08 \pm 0.1$ & $64.13 \pm 0.007$ & $\mathrm{n} / \mathrm{a}$ & 9448-9328 & 9653-9309 & 9363-9318 & 9395-9302 \\
\hline AAR-26657 & 2217 & 2054 & $\begin{array}{l}\text { Wood charcoal: } \\
\text { indet. twig }\end{array}$ & $9900 \pm 56$ & $29.16 \pm 0.2$ & $-11.37 \pm 0.11$ & $58.13 \pm 0.01$ & $1.13 \pm 0.01$ & 9439-9286 & 9653-9257 & $9648-9363$ & $9660-9343$ \\
\hline AAR-26656 & 2224 & 2054 & $\begin{array}{l}\text { Wood charcoal: } \\
\text { Amygdalus }\end{array}$ & $10024 \pm 50$ & $28.71 \pm 0.18$ & $-25.34 \pm 0.1$ & $60.985 \pm 0.007$ & $1.045 \pm 0.007$ & 9745-9416 & 9808-9344 & $9648-9363$ & $9660-9343$ \\
\hline \multicolumn{9}{|c|}{ Combine Boar Pit } & 9644-9325 & 9658-9316 & $9648-9363$ & $9660-9343$ \\
\hline AAR-26655 & 2166 & 2044 & $\begin{array}{l}\text { Wood charcoal: } \\
\text { Amygdalus }\end{array}$ & $9917 \pm 27$ & $29.09 \pm 27$ & $-26.18 \pm 0.11$ & $61.97 \pm 0.01$ & $\mathrm{n} / \mathrm{a}$ & 9373-9304 & 9442-9295 & $9440-9352$ & $9451-9330$ \\
\hline AAR-26658 & 2262 & 2062 & $\begin{array}{l}\text { Wood charcoal: } \\
\text { Salicaceae }\end{array}$ & $9901 \pm 41$ & $29.16 \pm 0.15$ & $-25.01 \pm 0.11$ & $56.02 \pm 0.01$ & $1.13 \pm 0.01$ & 9379-9291 & 9641-9265 & $9442-9352$ & $9651-9327$ \\
\hline AAR-26659 & 2243 & 2061 & $\begin{array}{l}\text { Wood charcoal: } \\
\text { Pistacia }\end{array}$ & $9912 \pm 26$ & $29.12 \pm 0.1$ & $-23.79 \pm 0.11$ & $61.49 \pm 0.01$ & $\mathrm{n} / \mathrm{a}$ & 9368-9303 & 9441-9292 & $9438-9352$ & $9446-9335$ \\
\hline
\end{tabular}


of bone, the contents of the pit were lifted as a block. The bones removed to enable the block to be encased in plaster prior to lifting were sent to the Natural History Museum of Denmark, University of Copenhagen, for study before being returned to Iran in 2017. In 2017 a conservator from the museum travelled with the team to excavate the material from the lifted block under laboratory conditions.

The excavations employed intensive sediment sampling and flotation to recover charred botanical material from the sediments. In this process great care was taken to differentiate samples from contexts obviously disturbed by animal burrowing and deposits that were in situ. This enabled us to retrieve charred botanical material from in situ deposits for Accelerator Mass Spectrometry dating, carried out at the University of Aarhus AMS Centre. Our new dates suggest that occupation at Asiab was earlier than previously suggested, with dates falling between 9648 and 9310 cal вС $(68.2 \%$ confidence; 9660-9294 cal BC at $95.4 \%$ confidence; Fig. 4; Table 1). Two dates were obtained from materials recovered from the fill of the 'boar pit'. When these two dates are combined in OxCal 4.3 they indicate a range between 9648 and $9363 \mathrm{cal}$ вс $(68.2 \%$; 9660 9343 cal BC at $95.4 \%$ confidence). Although two of the dates produced low agreement values when modelled in OxCal, the divergence is minor and all other dates have normal or good agreement values. These dates are very consistent and resolve previous ambiguity and disagreement between the dates obtained using bulk radiocarbon dating by Howe (1983) and dating of animal bone collagen by Zeder (2008). The new dates suggest that the occupation at Asiab falls at the very beginning of the Early Neolithic in the central Zagros, partially overlapping with, but not quite as early as, the dates obtained by Matthews et al. (2013) from Trench 1 at Sheikh-e Abad where the occupation spans 10,100-9140 cal BC $(95.4 \%$ confidence).

\section{Suidae: wild or domesticated}

Before we discuss the number of animals present in the pit and why remains of these animals were interred in such a manner, it is of importance to establish whether the Suidae remains represent the bones of wild and/or domestic animals. The work by Bökönyi (1977) suggested that the remains of Suidae from the original excavations at Asiab were wild boar. The measurements provided in the original report are incorporated into the analysis presented here (differentiated by colour in the figures). Research on the faunal remains from the contemporary site of Hallan Çemi in southeastern Turkey led Rosenberg et al. $(1995 ; 1998)$ to argue for the presence of domestic pigs based on size, high kill-off of juveniles and a bias towards males. Peters et al. (1999) have since questioned the domestic status of the Hallan Çemi remains, pointing out that 22 of the 23 upper and lower, second and third molars from Hallan Çemi fall within the size range of molars of southwest Asian wild boar, and the other falls within the overlap between wild boar and domestic animals. It should be mentioned that it remains unknown how long after humans started influencing animal breeding and the population structure of animal herds that changes to animal body-size might be expected. If the slaughter of males at a younger age was significant, then a size change in the overall population, as reconstructed from the archaeological evidence, would be expected quite quickly as the large males are removed from the sample. However, a change in body-size as a result of selective or unintentional breeding causing a change in the genetic variability of the animal population might take longer to manifest. Peters et al. (1999) also argued that a high proportion of juveniles and bias towards males can be found in many hunter-gatherer assemblages of wild boar and the current consensus opinion is that the Suidae from Hallan Çemi are wild animals.

With Hallan Çemi discounted, Çayönü at present has the best evidence for the transition from the management of wild boar to domesticated pig, which took place gradually between 9000 and 7500 bc. Ervynck et al. (2001) produced a detailed analysis of the Suidae remains from the sequence spanning this period and demonstrated a gradual shift to younger animals, size decrease and an increase of linear enamel hypoplasia. The latter indicates stress during the winter months, a condition shown to be common in domestic pigs. These results suggested a gradual intensification of the relationship between humans and Suidae, with most of the animals neither fully wild nor fully domestic, but managed livestock probably still breeding with wild animals. Price and Arbuckle (2013) have recently reanalysed the Suidae remains from Jarmo and concluded that that there is evidence for the early management of domesticated pigs in the Pre-Pottery Neolithic (PPN), whereas earlier publications (Flannery 1983; Reed 1960; Stampfli 1983) have suggested that domestication occurred later in the sequence in the Pottery Neolithic (PN). The frequency of Suidae at Jarmo varied between 2 and 7 per cent and after some of the bones from PN levels were reassigned to the PPN levels, Price and Arbuckle (2013) suggested that the presence of 


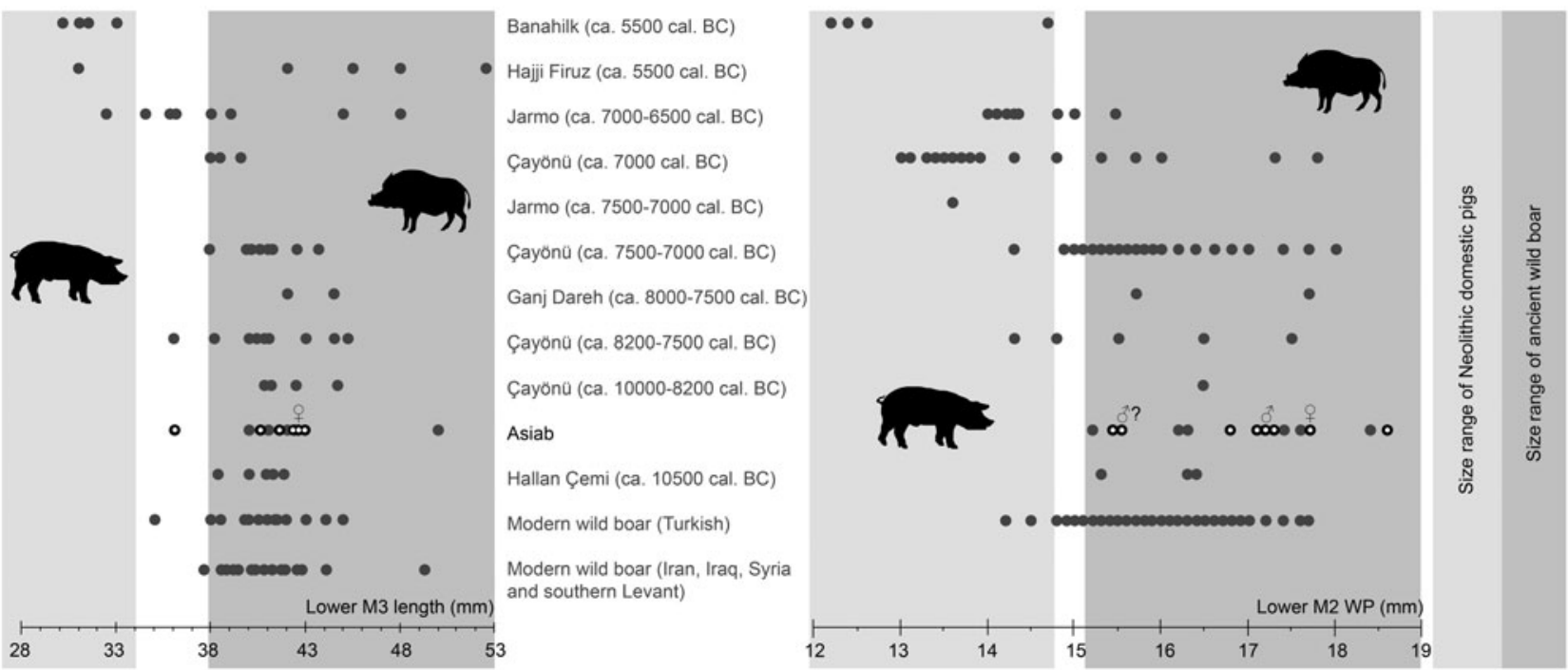

Figure 5. Comparison of length of lower third molars and width of the posterior cups of lower second molars from Banahilk (Kusatman 1991), Hajji Firuz (Meadow 1983), Jarmo (Price \& Arbuckle 2013), Çayönü (Eroynck et al. 2001), Ganj Dareh (Hesse 1978), Asiab (Bökönyi 1977) and Asiab new data (black circles with white dot), Hallan Çemi (Redding E Rosenberg 1998), modern Turkish wild boar (Kusatman 1991), modern wild boar from Iran, Iraq and southern Levant (Flannery 1983). Widths of the second molars from the original excavations at Asiab were presented in a graph in Price and Arbuckle (2013) based on the measurements by Bökönyi (1977), but the origin of these data is uncertain as Bökönyi did not present these data in the book. The grey zones are the inferred size of wild boar and domestic pigs with measurements in the white zone between not interpreted as either wild or domestic.

smaller animals in the PPN layers also demonstrated the presence of managed pigs at an intermediate stage of domestication in the earlier phases of the settlement. The evidence suggests that the intensification of the relationship between humans and pigs was a long process and the early managed pigs were far from the considerably smaller animals present at sixth-millennium bc sites like Banahilk (Kusatman 1991).

The measurements of molars shown in Figure 5 (Table 2) indicate that the Suidae at Asiab had not undergone any of the size changes associated with domestication. The size of the third molars is also similar to those from wild boar populations in Turkey, Iran, Iraq, Syria and the southern Levant. Flannery (1983) showed that there was no size difference between the teeth of wild boar from different environments in these areas. Nor did these teeth

Table 2. Lower M3 lengths and lower M2 WP measurements $(\mathrm{mm})$ used in Figure 5.

\begin{tabular}{|l|l|}
\hline $\begin{array}{l}\text { Measurement } \\
\text { description }\end{array}$ & \multicolumn{1}{|c|}{ Measurements (mm) } \\
\hline Lower M3 length & $36.1,40.6,41.7,42.4,42.60,42.8$ \\
\hline Lower M2 WP & $\begin{array}{l}15.5,15.50 ?, 16.8,17.1,17.2 ð, 17.3, \\
17.70,18.6\end{array}$ \\
\hline
\end{tabular}

vary markedly between males and females, which may otherwise have introduced problems with the use of molar size for determining domestic status. The use of the length of the third molars allows the data from the original excavations produced by Bökönyi (1977) to be incorporated. Kusatman (1991), however, argued that the breadth of the molars was more useful in separating the wild and domestic Suidae. Lengths of molars can be influenced by wear, and widths are better criteria for the separation of wild boars and domestic pigs. The width of the posterior cusp of the lower second molar is also shown in Figure 5 and the differentiation between wild boars and the domestic animals at Çayönü, Jarmo and Banahilk is evident. There is therefore solid evidence to argue that the assemblage from Asiab consists purely of wild boar.

The breadth of the distal tibia and the length of the astragalus are also measurements well suited for the separation of wild boar and domestic pig (Albarella \& Payne 2005). In a paper addressing the long-term changes in the morphology from wild boar to domestic pigs in the northern Fertile Crescent, Price and Evin (2019) compared these measurements to those from different millennia. These post-cranial bones were not common in the new assemblage from Asiab, but those published by 
Feasting on Wild Boar in the Early Neolithic

Bökönyi (1977) are larger than those from later sites with domestic animals present (Fig 6). This evidence confirms that the species present were wild boar and suggests that the material studied by Bökönyi (1977) was not as mixed as we originally feared given the amount of disturbance at the site noted in 2016. All of the above comparisons should take into account the difference in size between the modern and ancient wild boar, most noticeable in the post-cranial skeleton, possibly as a result of climate change and hunting pressure (Price \& Evin 2019). Use of the Log Standard Animal Index allows measurements taken on different elements to be compared. Figure 7 shows the data from Asiab in comparison to other sites in the Zagros and offers a better visualization of the measurements of the post-cranial skeleton. The data clearly support the conclusion that the Suidae present at Asiab were wild boar.

How many boars and the age/sex composition of the assemblage

A large proportion of the bones had to be removed during the exposure of the block prior to lifting and these were bagged in groups to keep fragmented parts together. Every attempt was made to reconstruct the bones in these bags, but much of the material was very fragmentary. In order to try and gain an accurate estimate of the number of boar mandibles and crania in the pit, the method of recording the presence/absence of clear zones was used. Ten zones were defined on the mandible and 12 on the crania. These provided coverage of the whole skull and were easily recognizable parts of the bones that could be recorded as present or absent for each individual fragment from the pit (Fig. 8). The results suggested that the skulls in the pit were initially more or less complete and represented a minimum of 19 individuals. Furthermore, the total number is unlikely to be any more than this.

Determining the ages of the boars was based on tooth eruption and wear. The basic tooth-wear stages were recorded following the system of Grant (1982). Lemoine et al. (2014) suggested that the potential of the data could be maximised by dividing it into broader and narrower categories. The finer resolution of narrow categories allows more subtle differences in the mortality profiles to be compared whilst the use of broader categories permits more of the fragmentary material to be assigned to an age group thereby increasing sample size. Lemoine et al. (2014) further proposed that both the mandibular and maxillary dentition be used in order to boost the number of specimens. Whilst this is suited to a typical assemblage of faunal material, the material

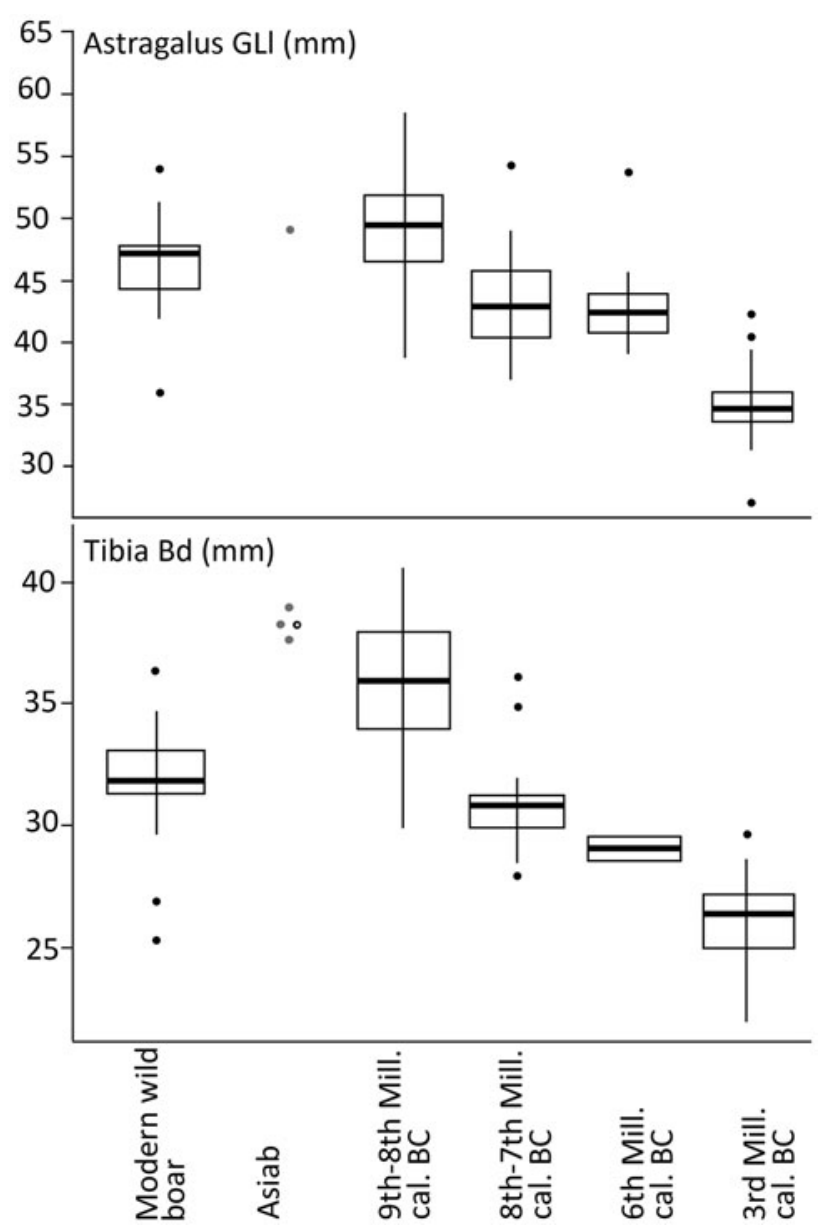

Figure 6. Comparison of the measurements taken on Suidae tibiae and astragali to long term changes in size shown by Price and Evin (2019) to include the Asiab data from the new excavation in black with white central dot and that published by Bökönyi (1977) in grey.

from the pit at Asiab is entire skulls and there is no need to duplicate the data concerning age from the mandibular and the maxillary teeth. Table 2 provides a summary of the number of fragments, ranging from isolated teeth to almost complete tooth rows, divided into the various categories presented by Lemoine et al. (2014). Where any additional information concerning the sex of the aged fragment was available, this has been included. This indicates that the age range of the boar represented in the pit is wide. Broad age categories could be assigned to parts of 15 right mandibles. But due to differences between the left and right mandibles in the narrower age groups, it is possible to determine the age of 18 of the 19 boar represented by the faunal remains. In other words, when using 10 categories (Lemoine et al. 2014), none of the right mandibles was in stage 5 (12-16 months), but one left mandible was 


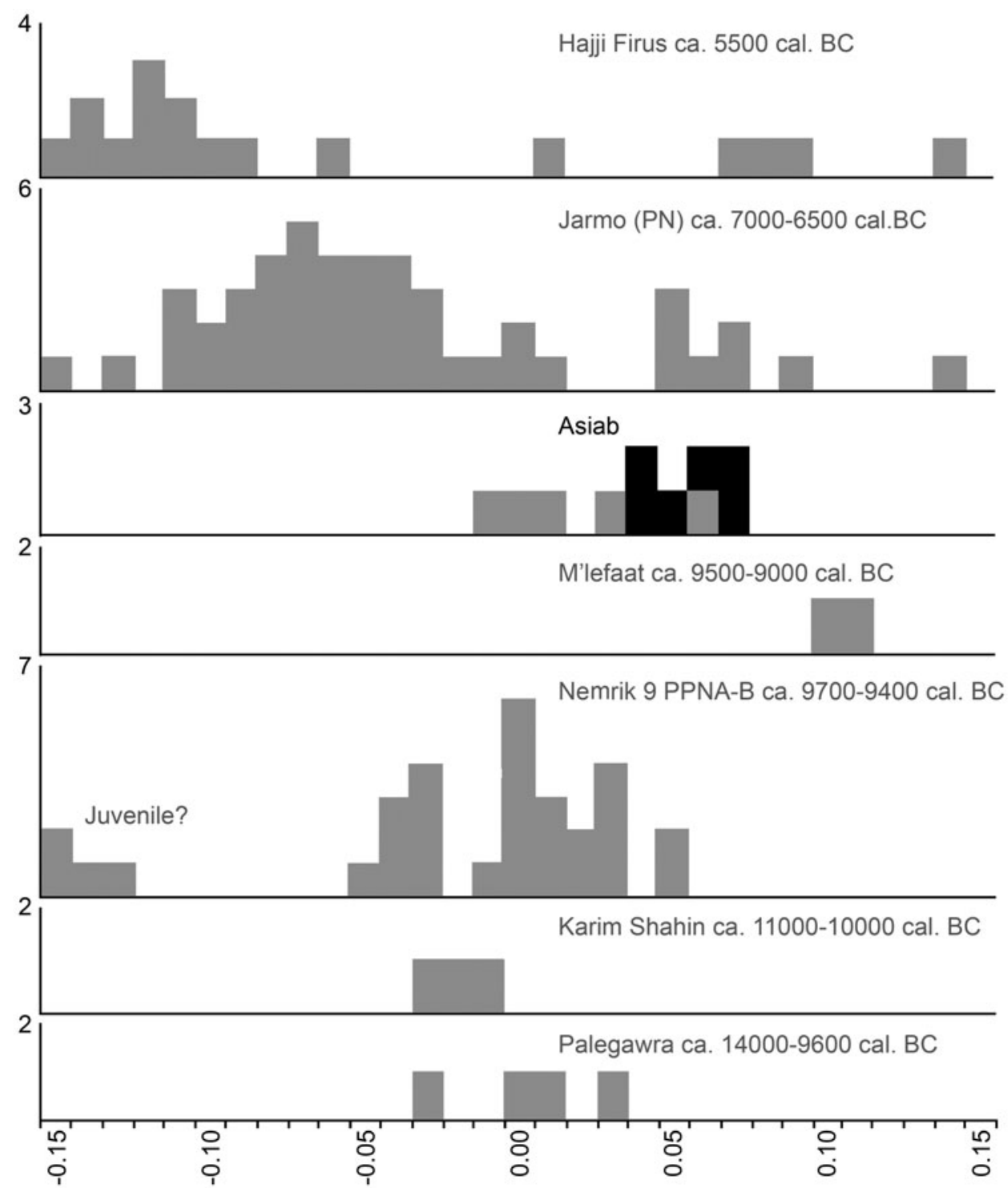

Figure 7. Comparison of the LSI of wild boar and domestic pig bones from sites across the Zagros. Modified from Price and Arbuckle (2013) from original data published by Meadow (1983), Bökönyi (1977), Turnbull (1983),

Lasota-Moskalewska (1994), Stampfli (1983) and Turnbull and Reed (1974). The small bones from Nemrik 9 may have been juvenile. LSI calculated from the standard female wild boar published by Hongo and Meadow (1998); where more than one measurement was taken on a bone the average LSI was used. Black indicates measurements taken on bones from the 'boar pit'.

in this stage, so this probably represents a different animal. Two left mandibles in stage 2 have no counterpart in the right mandibles and therefore probably derive from different animals than the 15 represented in the broader four age groups (Lemoine et al. 2014). Combining this information shows that nine of the boar were under a year old; the rest comprised a wider age range of animals including some older adults and one senile individual (Fig. 9a). The presence of a single metacarpal III or IV fragment from a neonatal boar suggests that not all of the boar are represented by the skulls, or the bone was accidentally incorporated into the pit fill.

In Figure 10 survivorship curves based on the three age categories in Tables $3 \& 4$ indicate that the Asiab profile is more similar to sites where domestic animals are present, as opposed to the hunted wild boar represented by Suidae from Hallan Çemi (Lemoine et al. 2014). The assemblage from the pit at Asiab is, however, small compared 


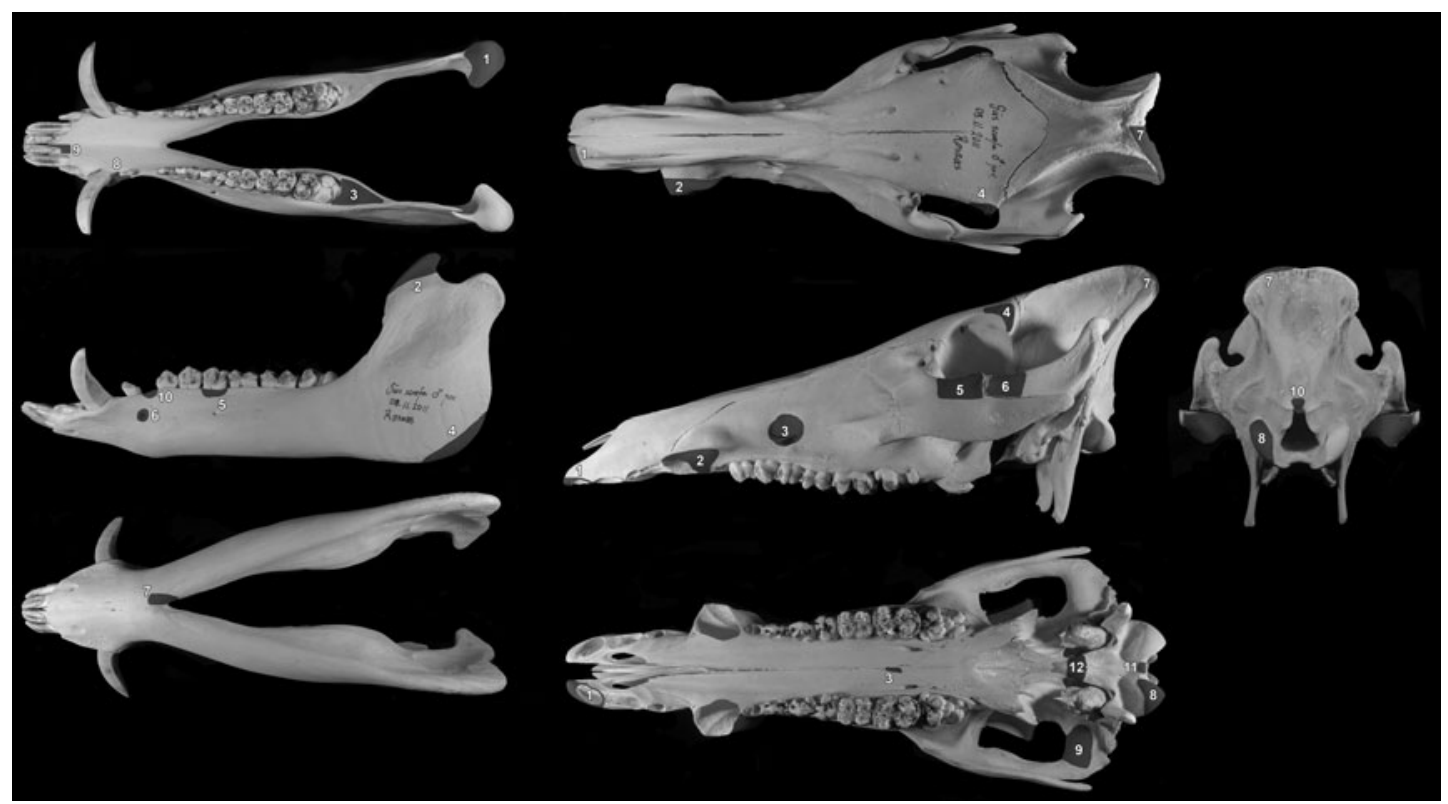

Figure 8. Zones of the mandible and crania used to quantify the completeness of the skulls and calculate the minimum number of individuals (MNI).

to the other assemblages, which also represent occupation debris. There is no other indication that the Asiab boars were under human management, but more young animals are present in the assemblage compared to Hallan Çemi. Interpretation of the mortality profiles of boars/pigs is difficult and the data could fit with a managed population structure or targeted female and young boar groups. The assemblage from Asiab represents a very particular type of deposit where the crania and mandibles of the boar were selectively placed into the pit and it is impossible to determine why specific animals were chosen. The composition of animals may therefore have little in common with the animals that formed the mainstay of the hunted fauna. Wild boars tend to form a low proportion of assemblages from Neolithic sites in the Taurus and Zagros, and as such the interment of many boars appears to represent a special hunting activity rather than day-to-day prey. Exceptions can be found such as at Hajji Firuz (Meadow 1983), Çayönü (Hongo et al. 2009) and Hallan Çemi (Rosenberg et al. 1998), but even at these sites Suidae are not the most frequent species. The choice of species for contexts such as the pit could potentially be related to a perception of boars as dangerous animals that were more risky to hunt than others. Even the young animals under a year of age are likely to have been ferociously protected by their mothers.

Although the data presented in Table 5 suggest that there were more females than males represented, this particular dataset only includes fragments where the canines or the alveoli for the canines could be clearly identified as male or female and combined with a determination of age (Mayer \& Brisbin 1988). Some of the mandibles, especially those of males, were chopped through the anterior part of the bone around the area of the diastema thereby separating the premolars and molars that can be aged more accurately from the alveoli of the canines or the canines that can be sexed. Furthermore, the posterior part of the mandible that included the tooth row was often not associated with the ventral area, so the size of the cavity for the canine under the tooth row was often absent. Table 3 shows a summary of fragments identified as male and female demonstrating that at least six males and at least seven females were present. Therefore evidence indicates that boars were not selected due to sex for the unusual deposit of skulls in the pit.

\section{Other elements present}

A few post-cranial bones of wild boar were also present in the pit. These are summarized in Table 6 and mainly include the major meat-bearing bones, especially those of the forelimb.

\section{Evidence of processing}

A large proportion of the crania and post-cranial bones have cut and chop marks, which suggest processing of the carcasses (Table 7; Fig. 9d, f \& g). These demonstrate that the flesh, marrow within the jaw 


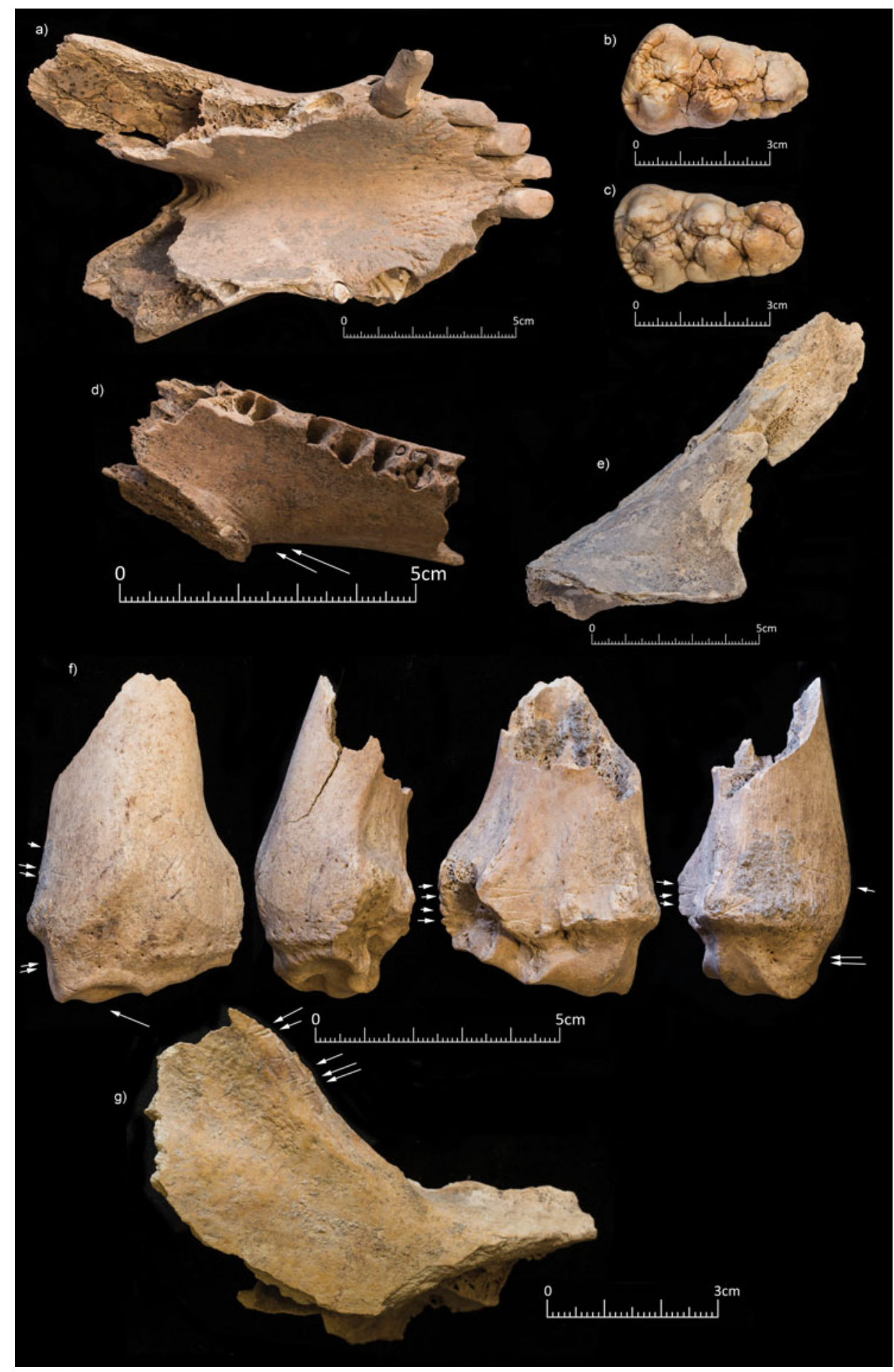

Figure 9. Some of the bones recovered from the 'boar pit'. (a) Anterior part of a mandible of very old female boar; (b) lower third molar not yet fully formed as evidenced by the enamel texture; (c) third molar with very minimal wear; (d) mandible with chop marks; (e) unshed red deer antler fragment; $(f)$ radius with cut marks; $(g)$ mandible with cut marks.

and tongues were removed. We cautiously estimate, based on data from Petone et al. (1995) for wild boar from Italy, that 19 boars would have produced a minimum of $700 \mathrm{~kg}$ of dressed weight, including meat, heads, skins and bones. Taking into account discarded parts of the carcass such as skin and 

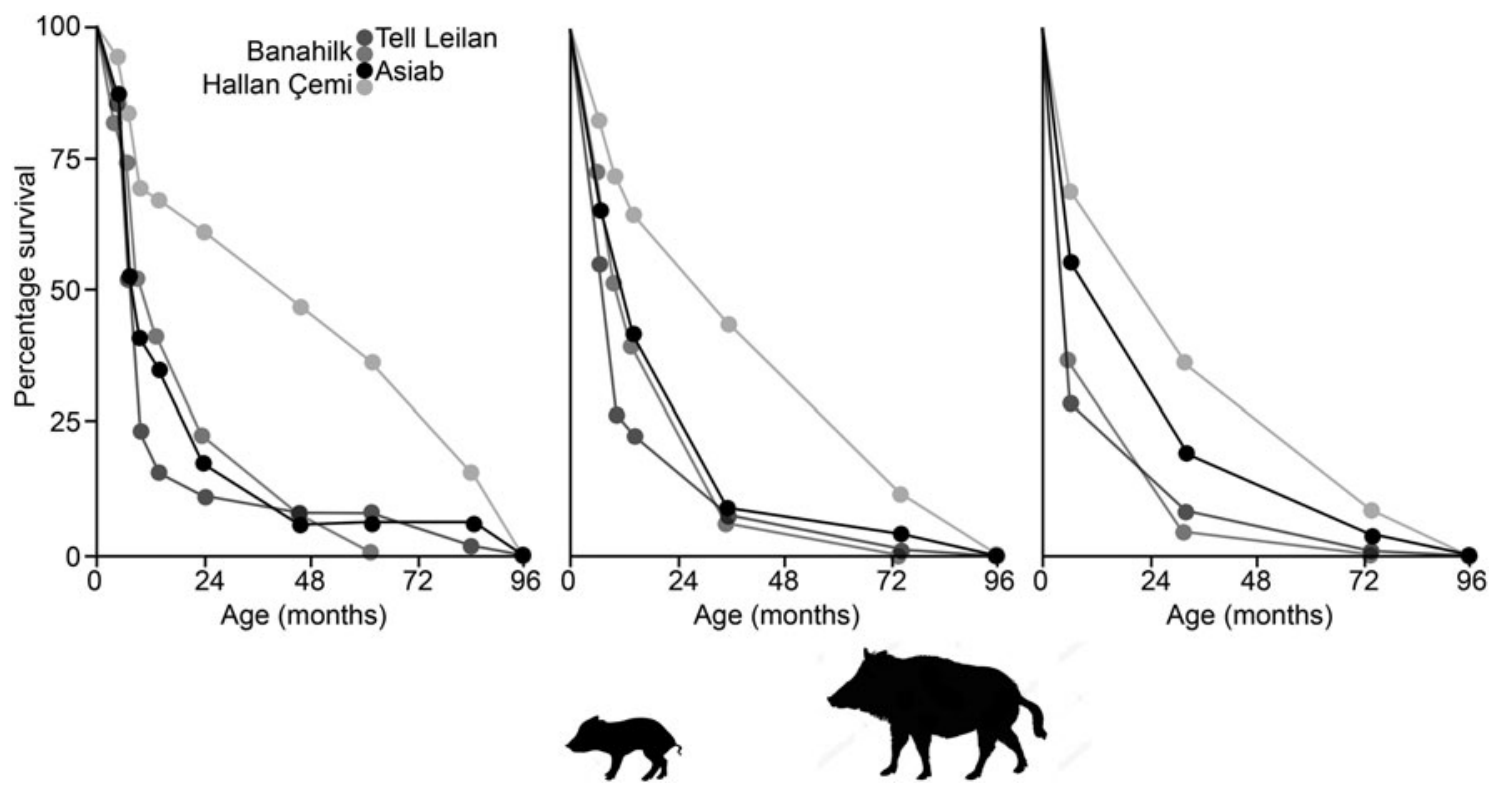

Figure 10. Survivorship curves comparing the data from the Asia pit to assemblages of wild and domestic Suidae from Hallan Çemi, Banahilk and Tell Leilan (Lemoine et al. 2014). Ages plotted are the mid value of the age range suggested with the graphs showing the data when divided according to the 'Specific', 'Simplified-A' and 'Simplified-B' groupings.

Table 3. Number of fragments assigned to different age categories using the Lemoine et al. (2014) system.

\begin{tabular}{|c|c|c|c|c|c|c|c|c|c|c|c|}
\hline Specific & $\begin{array}{c}\text { Estimated } \\
\text { age }\end{array}$ & Left & Right & $\begin{array}{c}\text { Simplified- } \\
\text { A }\end{array}$ & $\begin{array}{c}\text { Estimated } \\
\text { age }\end{array}$ & Left & Right & $\begin{array}{c}\text { Simplified- } \\
\text { B }\end{array}$ & $\begin{array}{c}\text { Estimated } \\
\text { age }\end{array}$ & Left & Right \\
\hline 1 & $<1$ month & & & A & $<1$ month & & & I & 0-12 months & 4 & $5+29$ \\
\hline 2 & 3-5 months & 2 & & B & 3-8 months & 2 & 5 & II & $\begin{array}{l}12-52 \\
\text { months }\end{array}$ & 5 & $3+19$ \\
\hline 3 & 6-8 months & & $\begin{array}{l}5+ \\
19\end{array}$ & C & 8-12 months & 1 & $2 q$ & III & $\begin{array}{l}52-96 \\
\text { months }\end{array}$ & 1 & $\begin{array}{l}1+ \\
19+10\end{array}$ \\
\hline 4 & 8-12 months & 1 & 19 & D & $\begin{array}{l}12-16 \\
\text { months }\end{array}$ & 1 & 1 & IV & >96 months & 19 & 19 \\
\hline 5 & $\begin{array}{l}\text { 12-16 } \\
\text { months }\end{array}$ & 1 & & E & $\begin{array}{l}18-52 \\
\text { months }\end{array}$ & 3 & $2 q+10^{\star}$ & & & 11 & 15 \\
\hline 6 & $\begin{array}{l}18-30 \\
\text { months }\end{array}$ & 2 & $10^{*}$ & F & $\begin{array}{l}52-96 \\
\text { months }\end{array}$ & 1 & & & & & \\
\hline 7 & $\begin{array}{l}30-52 \\
\text { months }\end{array}$ & & 29 & G & >96 months & 1 우 & 19 & & & & \\
\hline 8 & $\begin{array}{l}52-72 \\
\text { months }\end{array}$ & & & & & 9 & 12 & & & & \\
\hline 9 & $\begin{array}{l}\text { 72-96 } \\
\text { months }\end{array}$ & & & & & & & & & & \\
\hline \multirow[t]{2}{*}{10} & $>96$ months & 19 & 19 & & & & & & & & \\
\hline & & 7 & 11 & & & & & & & & \\
\hline
\end{tabular}

bone, the total weight of edible animal product from the 19 boars at Asiab probably fell between 350 and $500 \mathrm{~kg}$, even if half of the animals were under one year of age. It is very difficult to estimate the number of people that this supply of meat could have fed, but based on general data of meat consumption per day compiled by Kelly (2013, 72-3, tables 3-6), an appropriate average value for a hunter-gatherer group in this sort of environment likely fell between 0.2 and $0.5 \mathrm{~kg}$ of meat per person per day. If we assume 
Table 4. Wear stage of isolated teeth and mandibular rows with corresponding Lemoine et al. (2014) groupings of the remains used to generate Table 2. For individual teeth the number of teeth is shown with the wear stage in brackets; each tooth type is shown in a separate cell with the wear stage of the teeth present indicated. The Lemoine et al. (2014) stage is the row in the cells to the right with a dash indicating that a wear stage could not be assigned.

\begin{tabular}{|c|c|c|c|c|c|c|c|c|}
\hline & & & \multicolumn{6}{|c|}{ Lemoine et al. (2014) age class } \\
\hline \multicolumn{3}{|c|}{ Individual teeth } & \multicolumn{2}{|c|}{ Specific system } & \multicolumn{2}{|c|}{ Simplified-A system } & \multicolumn{2}{|c|}{ Simplified-B system } \\
\hline Tooth & Left & Right & Left & Right & Left & Right & Left & Right \\
\hline $\mathrm{dp} 4$ & $1(8), 1(10)$ & $1(11+)$ & 2,2 & 3 & B,B & B & I,I & I \\
\hline $\mathrm{P} 4$ & $1(8)$ & 1\%P4(7) & 5 & 49 & $\mathrm{D}$ & Co & II & I우 \\
\hline M1 & & 1(11), 1ㅇ⒀ & & ,79 & - & Eq & II & III \\
\hline M2 & $1(3-6), 1(3-6)$ & 2(3) & - & 3,3 & _E & $\mathrm{B}, \mathrm{B}$ & $\mathrm{I}, \mathrm{II}$ & $\mathrm{I}, \mathrm{I}$ \\
\hline \multirow[t]{12}{*}{ M3 } & $\begin{array}{l}\text { 1(3), 2(3-6), 3(7), 2(7-8), 1(7-9), } \\
1(9), 1(10-11)\end{array}$ & 2(3), 1(7), 1(7-9), 1(9) & 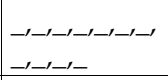 & $\begin{array}{l}-\prime \prime \prime-\prime \prime \prime \\
-\end{array}$ & 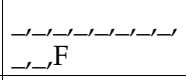 & $\begin{array}{l}-\prime-\prime-\prime \\
- \\
\end{array}$ & 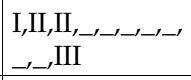 & $\begin{array}{l}-\prime \prime-\prime \prime \\
-\end{array}$ \\
\hline & \multicolumn{2}{|c|}{ Tooth rows } & & & & & & \\
\hline & M1(11)+M2(10) & $\begin{array}{l}\text { P4(heavy)+M1 } \\
\text { (heavy)+ } \\
\text { M2(heavy)+M3(9) }\end{array}$ & 6 & - & E & - & & II,III \\
\hline & $\mathrm{M} 1(14)+\mathrm{M} 2(11)+\mathrm{M} 3(8)$ & $\begin{array}{l}\text { oP4(medium)+ } \\
\text { M1(12-13)+M2(12) } \\
+ \text { M3(9) }\end{array}$ & - & \$7 & - & oE & & III, ᄋIII \\
\hline & M1(11)+M2(10)+M3(9) & $\begin{array}{l}\text { oP4(10)+M1(12)+M2 } \\
(11)\end{array}$ & 6 & $\$ 6$ & E & ot $\mathrm{E}$ & & III, ठIII \\
\hline & $\begin{array}{l}\mathrm{dp} 4(11)+ \\
\mathrm{M} 1(9-10)+\mathrm{M} 2(6)\end{array}$ & M1(7)+M2(crypt) & 4 & 3 & C & B & & I,I \\
\hline & & $\mathrm{P} 4(14)+\mathrm{M} 1(17-18)$ & & - & & - & & - \\
\hline & & $\mathrm{P} 4(8)+\mathrm{M} 1(10)+\mathrm{M} 2(9)$ & & - & & $\mathrm{D}$ & & II \\
\hline & & $\mathrm{P} 4(3)+\mathrm{M} 1(8)$ & & 3 & & B & & I \\
\hline & & odp4(12)+M1(7) & & $\$ 3$ & & क् & & ᄋI \\
\hline & & $\mathrm{M} 1(10)+\mathrm{M} 2(7)$ & & - & & $\mathrm{D}$ & & II \\
\hline & \multicolumn{2}{|c|}{ @senile - incisors in very heavy wear (see Fig. 8a) } & \multicolumn{2}{|c|}{$\$ 10$} & \multicolumn{2}{|l|}{ $\mathrm{G}$} & \multicolumn{2}{|l|}{ ९IV } \\
\hline
\end{tabular}

that the boar pit at Asiab represent the remnants of a feasting event, where people would likely have consumed more than their daily average of meat (e.g. around $0.4-1 \mathrm{~kg} /$ person), the boars would have provided sufficient food for 350-1200 adult individuals. It is, however, entirely possible that the event extended over more than a single day, reducing the number significantly. Nevertheless, the above estimates either suggest a large aggregation of people

Table 5. Male and female canines and alveoli for the canines present excluding canine fragments that were less than half of the original tooth.

\begin{tabular}{|c|c|c|}
\hline Mandibular & Left & Right \\
\hline Alveoli & $60^{\star}+10^{\star} ?, 39+1$ ㅇ? & 40,69 \\
\hline Canine & 39 & $3 ठ+1{ }^{\star} ?, 7 q$ \\
\hline Maxillary & Left & Right \\
\hline Alveoli & 30,49 & 400,49 \\
\hline Canine & 20,10 & - \\
\hline
\end{tabular}

or considerable wastage of meat, i.e. deliberate overkill of boars. Given what we know of rough population estimates for late Epipalaeolithic and Early Neolithic groups in southwest Asia, the latter explanation seems more likely, since there is no evidence for aggregation at Asiab in terms of site size or density of finds. Having said that, it is important to consider whether the wild boar were killed during one event or over a longer period of time, and if their placement together in the pit is the result of curation of skulls. While it is clear that the remains were deposited during a single event, it is harder to demonstrate that the skulls were not curated. All we can state with confidence is that there is no evidence for the weathering of the bone on any of the skulls, nor are there signs of wear that might indicate handling. The fact that the mandibles remained with the crania of the boars, i.e. that they were still attached or kept together in some way in all of the cases, would also seem to suggest that long-term curation did not occur, as 
Feasting on Wild Boar in the Early Neolithic

Table 6. Minimum number of elements of the post-cranial skeleton of wild boar in the pit at Asiab. Fusion information and metrical data also included.

\begin{tabular}{|l|c|c|l|l|l|}
\hline \multirow{2}{*}{ Bone } & \multicolumn{2}{|c|}{ MNE } & \multirow{2}{*}{ Proximal fusion } & \multicolumn{1}{c|}{ Distal fusion } & Measurements (mm) \\
\cline { 2 - 6 } & Left & Right & & 6 fused & $\begin{array}{l}\text { BT-40.1; Bd-54.4, BT-42.8; Bd-54.1, BT-42.3; } \\
\text { Bd-50.6, BT-40; Bd-54.2, BT-44.2 }\end{array}$ \\
\hline Humerus & 3 & 3 & - & $\begin{array}{l}1 \text { unfused, 1 fusing, } \\
2 \text { fused }\end{array}$ & BFd-38.3; Bd-39.2 (fusing); Bd-42.3, BFd-36.8 \\
\hline Radius & 1 & 3 & 1 fused & 1 fused, 2 unfused & \\
\hline Ulna & 1 & 2 & 1 fused & 1 unfused (neonatal) & \\
\hline Metacarpal III or IV & \multicolumn{1}{|c|}{1} & & 1 fused & Bd-37.9, Dd-34.0 \\
\hline Tibia & 0 & 1 & & 1 fused & \\
\hline Fibula & 0 & 1 & &
\end{tabular}

Table 7. Description of cuts and chop marks on the bones in the pit at Asiab compared to the MNE for the different elements.

\begin{tabular}{|c|c|c|c|c|}
\hline Bone & $\begin{array}{l}\text { Type } \\
\text { code }\end{array}$ & Description & Number & $\begin{array}{c}\text { Minimum number of } \\
\text { elements (MNE) }\end{array}$ \\
\hline \multirow[t]{5}{*}{ Crania } & $\mathrm{C} 1$ & $\begin{array}{l}\text { Longitudinal cut (cranial to caudal) on maxilla where zygomatic } \\
\text { bone and maxilla meet above or near the third molar }\end{array}$ & 2 & \multirow[t]{5}{*}{19} \\
\hline & $\mathrm{C} 2$ & Transverse (medial to lateral) cut on nasal bone & 1 & \\
\hline & C3 & $\begin{array}{l}\text { Transverse (medial to lateral) cut on the condyle adjacent to the } \\
\text { foramen magnum or on the styloid process }\end{array}$ & 8 & \\
\hline & $\mathrm{C} 4$ & $\begin{array}{l}\text { Transverse (medial to lateral) cut on occipital bone above the } \\
\text { foramen magnum area }\end{array}$ & 1 & \\
\hline & C5 & Oblique to longitudinal cut across frontal and parietal bone & 2 & \\
\hline \multirow[t]{5}{*}{ Mandible } & M1 & Medial-lateral cut on ramus above the third molar & 3 & \multirow[t]{5}{*}{38} \\
\hline & M2 & $\begin{array}{l}\text { Transverse cut lateral side-caudal edge on ramus below the } \\
\text { condyle }\end{array}$ & 15 & \\
\hline & M3 & Cuts on the lingual side of mandible below the teeth row & 2 & \\
\hline & M4 & Cut on the buccal side of mandible, below the teeth row & 3 & \\
\hline & M5 & Cut and chop at the canine, often splitting open the alveoli & 7 & \\
\hline \multirow[t]{2}{*}{ Humerus } & H1 & Transverse cut on medial side of distal diaphysis & 1 & \multirow[t]{2}{*}{6} \\
\hline & $\mathrm{H} 2$ & Diagonally cuts on lateral part of condyle & 1 & \\
\hline \multirow[t]{2}{*}{ Radius } & R1 & $\begin{array}{l}\text { Cuts transverse and longitudinal on all sides of the distal } \\
\text { diaphysis }\end{array}$ & 3 & \multirow[t]{2}{*}{4} \\
\hline & R2 & Cuts on the margins of the distal articulation & 1 & \\
\hline \multirow[t]{2}{*}{ Ulna } & $\mathrm{U} 1$ & $\begin{array}{l}\text { Transverse or longitudinal cuts on anterior side of diaphysis, } \\
\text { immediately above distal articulated surface }\end{array}$ & 2 & \multirow[t]{2}{*}{3} \\
\hline & $\mathrm{U} 2$ & Cuts on the distal articulation & 1 & \\
\hline Tibia & $\mathrm{T} 1$ & $\begin{array}{l}\text { Diagonal cuts on medial side of the diaphysis just above the distal } \\
\text { articulation }\end{array}$ & 1 & 1 \\
\hline $\begin{array}{l}\text { Unidentified long } \\
\text { bone }\end{array}$ & L1 & Transverse cuts on diaphysis & 1 & - \\
\hline
\end{tabular}

long-term curation would heighten the likelihood of crania and mandibles becoming separated. Given that the deposition of the skulls occurred as one concentrated event, that makes it somewhat more plausible that the animals were also killed, butchered and consumed as part of the same overall event.
Many mandibles appear deliberately broken to remove the canines, especially the larger ones of the males, and only fragments of the teeth themselves were present in the pit. The extracted teeth were possibly turned into pendants, which may have become important items of reference. They 


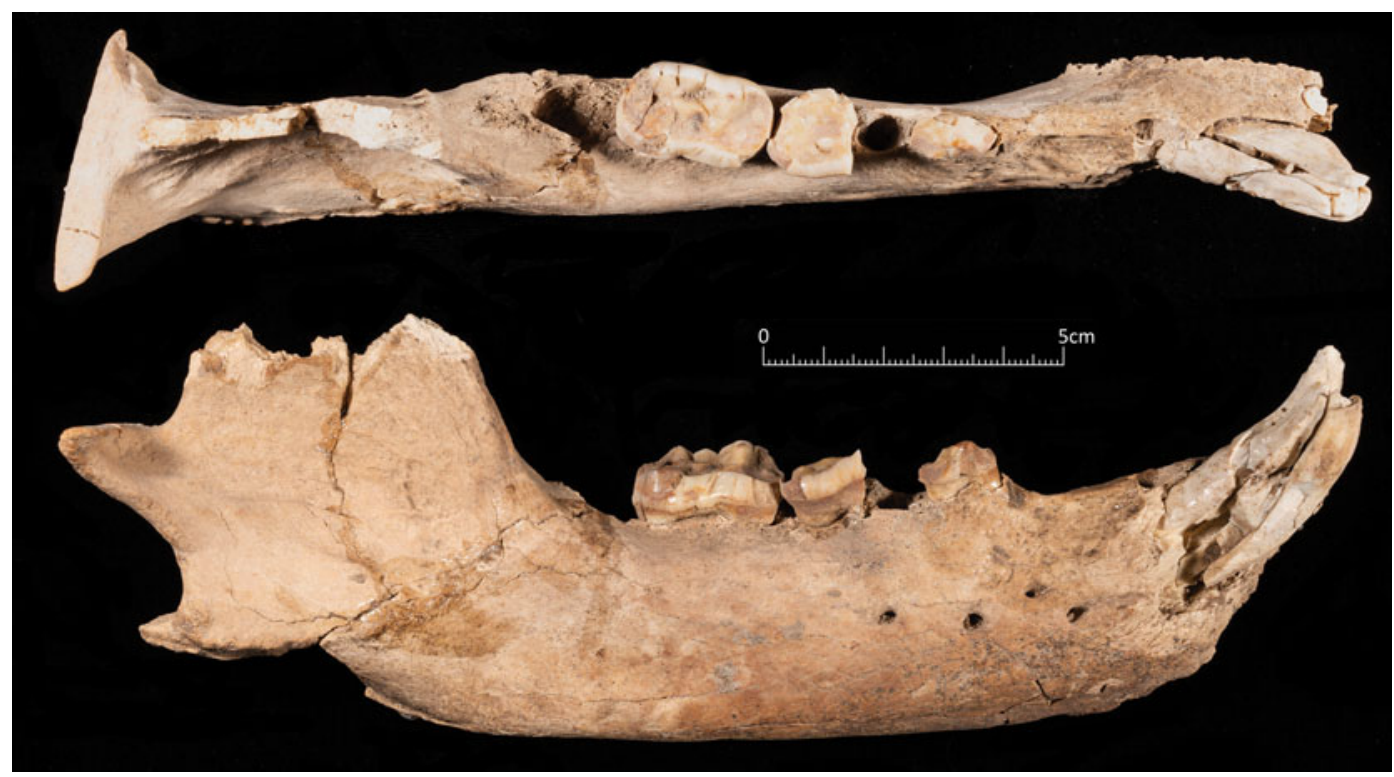

Figure 11. Part of the mandible of the brown bear recovered from the base of the pit. The cranium of the bear was too fragmentary to be clearly visible in a photograph.

may have been worn as items of commemoration which recalled the events of this particular feast.

\section{Other species present}

Two pieces of poorly preserved antlers were also present in the pit. The largest piece was identified as that of a red deer (Cervus elaphus) and was still attached to the frontal bone, indicating that the animal must have been killed during the rutting season (Fig. 9e). The other fragments could have derived from the same animal, but it is impossible to be certain. The skull of the bear (Fig. 11), which was found underneath the wild boars at the base of the pit, is comprised of a fragmentary cranium and both mandibles. The mandibles were found underneath the cranium, but slightly further forward. The bear skull was probably the first thing placed in the pit before the boar crania were placed to one side and the boar mandibles placed on the other. The size of the permanent dentition of the boar indicates that this was probably a large adult male brown bear (Ursus arctos). Brown bear was also present at Zawi Chemi Shanidar (Perkins 1964) and from the description in Solecki (1981) this bone was worked, although it is unclear which element the bone was or the context that it was recovered from. Remains of bear are not common in the Early Neolithic sites of the Zagros and therefore the bear remains at Asiab are noteworthy. Its inclusion in the pit was clearly significant. This was also a large animal which would not have been easily hunted, and pursuing it would have posed a considerable risk to the hunters Although the bear cranium and the antler remains are probably not directly related to feasting itself, their inclusion in the placed deposit would have signified other important aspects related to the ceremony that was performed in the building. It is not necessarily the case that the feast and the burial of all the remains occurred at the same time, but given the lack of bone weathering, no evidence for pit collapsing at the edges and the deliberate sealing of the pit, there probably was not an extended time gap between the accumulation of all the remains and their collective burial.

\section{Conclusions}

The Asiab 'boar pit' is clearly an unusual feature with an atypical assemblage of faunal material. Twiss (2008, table 1) suggests a number of archaeological signatures that could be used to identify feasting in the archaeological record, based on a review of ethnographic examples. The large and dense concentration of food remains in a special, placed deposit at Asiab certainly fulfils many of these criteria. The animals present in the pit are not the species most frequently hunted during the Early Neolithic in the region and the location of the pit in the centre of a large, possibly communal structure is notable. There is also evidence for the removal of trophy bones in the form of the large male canines. Twiss (2008) argued that feasts were increasingly important 
during the southern Levantine PPN as population density increased and the economy gradually shifted from hunting and gathering to plant cultivation and animal management. Evidence for feasting has been suggested as early as the Late Natufian at Hilazon Tachtit (Grosman et al. 2008) and Raqefet Cave (Munro \& Grosman 2010), while Hayden has interpreted many Natufian sites as potential feasting localities (Hayden 2004; 2011; Hayden et al. 2013). Evidence for feasting appears to increase in frequency thereafter in the Early Neolithic. One of the clearest examples of feasting is at the PPNB site of Kfar HaHoresh where the remains of at least eight aurochs were interred in a pit, which was sealed before a human burial was placed above (Goring-Morris \& Horwitz 2007; Horwitz \& Goring-Morris 2004). In the northern part of the Fertile Crescent examples of ritual activities involving animals can be found, even if their interpretation as evidence of feasting is less clear. A concentration of bones at Zawi Chemi Shanidar spread over at least $0.9 \times 1.0 \mathrm{~m}$ contained the skulls of 15 wild goats and wing bones of raptors, including four bearded vultures, one griffon vulture, seven white-tailed eagles, four small eagles and a great bustard (Solecki 1977). These were interpreted as atypical occupational waste and not the remains of a feast, but some 'ritual paraphernalia'. At Sheikh-e Abad was similar evidence, with four morphologically wild goat and one wild sheep skulls found aligned next to each other in two pairs with the sheep behind (Bendrey et al. 2013). The importance of the head of the animal is clear at many sites, with other wellknown examples of aurochs bucrania that could be associated with the visual impression of these, and suggests memorialization of specific feasts (Demirergi et al. 2014). Evidence for feasting is less clear, with the exception of Hallan Çemi where articulated portions of large mammals alongside bird remains suggestive of ritual activity were recovered from communal structures (Zeder \& Spitzer 2016). At Göbekli Tepe, the ritual and iconographic importance of animals is obvious (Peters \& Schmidt 2004), but Dietrich et al. $(2012,690)$ argue that deposits infilling the enclosures after their use consisted, amongst other material, of 'surprisingly large amounts of animal bones smashed to get to the marrow, clearly the remains of meals'. Whilst they interpret this as 'a strong indication of large-scale feasting' (Dietrich et al. 2012, 690), such deposits do not seem exceptional and it is usual for midden accumulating in abandoned structures to contain large quantities of animal bone. Feasting may well have been important, but often remains of communal consumption events were mixed with everyday waste. Unless there is a clear context that allows a single event to be recognized in the archaeological record, determining the importance of feasting from the zooarchaeological record is difficult. The difference between daily consumption and a feast is not as disparate as characterized by many archaeological studies (Twiss 2008). It is only when a ritual deposition of a feast leads to a recognizable archaeological context that we have clear evidence for these activities.

Despite what we consider to be strong evidence for a deposit that resulted from the ceremonial consumption of wild boar, we would simultaneously stress that the sacrifice of animals may also have played an important part. The remains of wild boar are not the only animal parts included in the deposit. As we described above, a brown bear skull was placed beneath the wild boar remains. Bear meat is not a meat typically selected by humans in Late Pleistocene/Early Holocene of southwest Asia. Furthermore, as our calculations indicated above the 19 boars represented in the Asiab pit would have produced a large amount of meat. The quantity of food gained from the carcasses would have exceeded the needs of a large group of people, even when taking into account that people would probably have consumed more than their average daily intake of meat at such a ceremonial feast. This remains the case even if we include the possibility that the feasting event lasted more than one day. We therefore suggest that feasting was not the only factor that resulted in the deposition of the boar skulls and the bear skull at Asiab. More animals were hunted and butchered than would have been required to feed the attendants of the feast. Additionally, the animals that were included in the pit would by most standards be considered dangerous creatures. Adult wild boars are powerful animals and many hunters consider them to be potentially hazardous to pursue. Even if not all the boars in the pit were of adult age, their hunt and pursuit would have still carried the risk of encountering the more dangerous adult boar. Similarly, the presence of a brown bear skull in the pit conjures up another hunt for a potentially lethal animal that had little or no subsistence benefit. It has been previously noted that wild and dangerous animals are an important aspect of Early Neolithic iconography (e.g. Hodder 2007; Hodder \& Meskell 2011; Peters \& Schmidt 2004;). We argue that the evidence from Asiab lends credence to the idea that dangerous animals played a significant role in early Neolithic cosmology in southwest Asia. They appear to have 
been the focus of intentional pursuit and were used for sacrifice and consumption at ceremonies.

Finally, the Asiab boar pit highlights that ideas about what it meant to be an Early Neolithic gatherer-hunter-cultivator in the central Zagros shared certain affinities with the iconography and practices attested elsewhere in the Fertile Crescent during the Early Neolithic. The comparative lack of research into the Early Neolithic in the central Zagros and western Iran generally has often led to this region being sidelined in discussions of the emergence and development of Early Neolithic societies and economies in southwest Asia. Our renewed work at Asiab, in accordance with results from other sites in the same region, underlines that this area was more firmly integrated into the Early Neolithic world than previously thought.

\section{Note}

1. The term Early Neolithic is used here as it is broadly contemporary with the PPNA (Pre-Pottery Neolithic A) in the southern Levant. In the Zagros region scholars also refer to this period as the Transitional Neolithic.

\section{Acknowledgements}

Excavations at Asiab were carried out by the Tracking Cultural and Environmental Change project, collaboration between the Research Institute for Cultural Heritage, the Iranian Centre of Archaeological Research, the Department of Archaeology at Razi University and the Center for the Study of Early Agricultural Societies at the University of Copenhagen. The project is generously funded by a grant from the C.L. David Collection and Foundation. We are grateful to the representatives of the Kermanshah office of the Cultural Heritage, Handicrafts and Tourism Organisation for their support and assistance during the fieldwork, as well as to all the members of the Asiab fieldwork team.

Pernille Bangsgaard Center for GeoGenetics University of Copenhagen Øster Voldgade 5-7 1350 København $\mathrm{K}$ Denmark Email: pernille.bangsgaard@snm.ku.dk

Lisa Yeomans Department of Cross-Cultural and Regional Studies Karen Blixens Plads 8, Bygning 10 2300 København $S$
Email:zhr605@hum.ku.dk

Hojjat Darabi

Razi University

Department of Archaeology

Iran

Email:hojjatdarabi@gmail.com

Kristian Murphy Gregersen

Natural History Museum of Denmark

University of Copenhagen

Gothersgade 130

1123 København K

Denmark

Email:kgregersen@snm.ku.dk

Jesper Olsen

Aarhus University

Department of Physics and Astronomy

Ny Munkegade 120

Building 1522

8000 Aarhus C

Denmark

Email: jesper.olsen@phys.au.dk

Tobias Richter

Department of Cross-Cultural and Regional Studies

Karen Blixens Plads 8, Bygning 10

2300 København $S$

Denmark

Email: richter@hum.ku.dk

Peder Mortensen

Department of Cross-Cultural and Regional Studies

Karen Blixens Plads 8, Bygning 10

2300 København $S$

Denmark

Email:pmortensen@hum.ku.dk

\section{References}

Albarella, U. \& S. Payne, 2005. Neolithic pigs from Durrington Walls, Wiltshire, England: a biometric database. Journal of Archaeological Science 32, 589-99.

Bendrey, R., G. Cole \& C.L. Tvetmarken, 2013. Zooarchaeology: preliminary assessment of the animal bones, in The Earliest Neolithic of Iran: 2008 excavations at Sheikh-E Abad and Jani, eds. R. Matthews, W. Matthews \& Y. Mohammadifar. Oxford: Oxbow, 147-61.

Bernbeck, R., 2004. Iran in the Neolithic, in Persiens Antike Pracht: Bergbau, Handwerk, Archäologie, eds. T. Stöllner, R. Slotta R. \& A. Vatandoust. Bochum: Deutsches Bergbau-Museum, 140-48. 
Bökönyi, S., 1977. The Animal Remains from Four Sites in the Kermanshah Valley, Iran: Asiab, Sarab, Dehsavar, and Siahbid. (BAR International series S34.) Oxford: British Archaeological Reports.

Braidwood, R.J., 1960. Seeking the world's first farmers in Persian Kurdistan: a full-scale investigation of prehistoric sites near Kermanshah. Illustrated London News 237(6325), 695-7.

Braidwood, R.J., 1961. The Iranian prehistoric project, 1959-1960. Iran Antiqua 1, 3-7.

Braidwood, R.J., B. Howe \& C.A. Reed, 1961. The Iranian prehistoric project: new problems arise as more is learned of the first attempts at food production and settled village life. Science 133(3469), 2008-10.

Darabi, H., 2015. An Introduction to the Neolithic Revolution of the Central Zagros, Iran. Oxford: Archaeopress.

Darabi, H., H. Fazeli, R. Naseri, S. Riehl \& R. Young, 2013. The Neolithisation process in the Seimareh Valley: excavations at East Chia Sabz, Central Zagros, in The Neolithisation of Iran: The formation of new societies, eds. R. Matthews \& H. Fazeli. Oxford: Oxbow, 55-75.

Darabi, H., R. Naseri, R. Young \& H. Fazeli, 2011. Absolute chronology of East Chia Sabz: a Pre-Pottery Neolithic site in western Iran. Documenta Praehistorica 38, 255-65.

Darabi, H., T. Richter \& P. Mortensen, 2018. New excavations at Tappeh Asiab, Kermanshah Province, Iran. Antiquity 92(361), E2. doi:10.15184/aqy.2018.3

Demirergi, D.A., K.C. Twiss, A. Bogaard, L. Green, P. Ryan \& S. Farid, 2014. Of bins, basins and banquets: storing, handling and sharing at Neolithic Çatalhöyük, in Integrating Çatalhöyük: Themes from the 2000-2008 seasons, ed. I. Hodder. Los Angeles (CA): UCLA Cotsen Institute of Archaeology, 91-108.

Dietrich, O., M. Heun, J. Nostroff, K. Schmidt \& M. Zarnkow, 2012. The role of cult and feasting in the emergence of Neolithic communities: new evidence from Göbekli Tepe, south-eastern Turkey. Antiquity 86, 674-95.

Ervynck, A., K. Dobney, H. Hongo \& R.H. Meadow, 2001. Born free? New evidence for the status of Sus scrofa at Neolithic Çayönü Tepesi (southeastern Anatolia, Turkey). Paléorient 27(2), 47-73.

Flannery, K.V., 1983. Early pig domestication in the Fertile Crescent: a retrospective look, in The Hilly Flanks: Essays on the pre-history of southwestern Asia, eds. T. C. Young, P.E.L. Smith \& P. Mortensen. (Studies in Ancient Oriental Civilization 36.) Chicago (IL): Oriental Institute, 163-88.

Goring-Morris, N. \& L.K. Horwitz, 2007. Funerals and feasts during the Pre-Pottery Neolithic B of the Near East. Antiquity 81, 902-19.

Grant, A., 1982. The use of tooth wear as a guide to the age of domestic ungulates, in Ageing and Sexing Animal Bones from Archaeological Sites, eds. B. Wilson, C. Grigson \& S. Payne. (AR British series 109.) Oxford: British Archaeological Reports, 91-108.

Grosman, L., N.D. Munro \& A. Belfer-Cohen, 2008. A 12,000-year-old Shaman burial from the southern
Levant (Israel). Proceedings of the National Academy of Science 105(46), 17665-9.

Hayden, B., 1990. Nimrods, piscators, pluckers and planters: the emergence of food production. Journal of Anthropological Archaeology 9, 31-69.

Hayden, B., 1995. A new overview of domestication, in Last Hunters - First Farmers: New perspectives on the prehistoric transition to agriculture, eds. T.D. Price \& A. Gebauer. Santa Fe (NM): School of American Research Press, 273-99.

Hayden, B., 2004. Sociopolitical organization in the Natufian, in The Last Hunter-Gatherers in the Near East, ed. C. Delage. Oxford: British Archaeological Reports, 236-308.

Hayden, B., 2011, Feasting and social dynamics in the Epipaleolithic of the Fertile Crescent, in Guess Who's Coming to Dinner: Feasting rituals in the prehistoric societies of Europe and the Near East, eds. G. A. Jiménez, S. Montón-Subías \& M.S. Romero. Oxford: Oxbow, 30-63.

Hayden, B., N. Canuel \& J. Shanse, 2013. What was brewing in the Natufian? An archaeological assessment of brewing technology in the Epipaleolithic. Journal of Archaeological Method and Theory 20(1), 102-50.

Helwing, B., 2003. Feasts as a social dynamic in prehistoric western Asia - three case studies from Syria and Anatolia. Paléorient 29(2), 63-85.

Hesse, B., 1978. Evidence for Husbandry from the Early Neolithic site of Ganj Dareh in Western Iran. PhD thesis, Columbia University.

Hodder, I., 2007. Çatalhöyük in the context of the Middle Eastern Neolithic. Annual Review of Anthropology 36, 105-20.

Hodder, I. \& L. Meskell, 2011. 'Curious and sometimes a trifle macabre artistry'. Some aspects of symbolism in Neolithic Turkey. Current Anthropology 52(2), 235-63.

Hongo, H, \& R.H. Meadow, 1998. Pig exploitation at Neolithic Çayönü Tepesi (southeastern Anatolia), in Ancestors for the Pigs, ed. S. Nelson. (MASCA Research Papers in Science and Archaeology 15.) Philadelphia (PA): University of Pennsylvania Museum of Archaeology and Anthropology, 77-98.

Hongo, H., J. Pearson, B. Öksüz \& G. Lgezdi, 2009. The process of ungulate domestication at Çayönü, southeastern Turkey: a multidisciplinary approach focusing on Bos sp. and Cervus elaphus. Anthropozoologica 44(1), 6378.

Horwitz, L.K. \& N. Goring-Morris, 2004. Animals and ritual during the Levantine PPNB: a case study from the site of Kfar Hahoresh, Israel. Anthropozoologica 29(1), 165-78.

Howe, B., 1983. Karim Shahir, in Prehistoric Archaeology Along the Zagros Flanks, eds. L.S. Braidwood, R. J. Braidwood, B. Howe, C.A. Reed \& P.J. Watson. (University of Chicago Oriental Institute Publications 105.) Chicago (IL): Oriental Institute, 23-154. 
Kelly, R.L., 2013. The Lifeways of Hunter-Gatherers. The foraging spectrum. Cambridge: Cambridge University Press.

Kozlowski, S.K., 1999. The Eastern Wind of the Fertile Crescent: Late prehistory of greater Mesopotamia lithic industries. Oxford: Archaeopress.

Kuijt, I., 2010. Near Eastern Neolithic Research: Directions and trends, in Life in Neolithic Farming Communities: Social organization, identity, and social differentiation, ed. I. Kuijt. New York (NY): Kluwer Academic, 311-21.

Kusatman, B., 1991. The Origins of Pig Domestication with Particular Reference to the Near East. PhD dissertation, University College London.

Lasota-Moskalewska, A., 1994. Nemrik 9: Pre-Pottery Neolithic Site in Iraq, Vol. 4: Animal remains. Warsaw: Wydawnictwa Uniwersytetu Warszawskiego.

Lemoine, X., M. Zeder, K.J. Bishop \& S.J. Rufolo, 2014. A new system for computing dentition-based age profiles in Sus scrofa. Journal of Archaeological Science 47, 179-93.

Matthews, R., W. Matthews \& Y. Mohammadifar, 2013. The Earliest Neolithic of Iran: 2008 excavations at Sheikh-E Abad and Jani. Oxford: Oxbow.

Mayer, J.J. \& I.L. Brisbin, 1988. Sex identification of Sus scrofa based on canine morphology. Journal of Mammalogy 69(2), 408-12.

Meadow, R.H., 1983. Appendix G: The vertebrate faunal remains from Hasanlu Period $X$ at Hajji Firuz, in Hasanlu Excavation Reports Volume I: Hajji Firuz Tepe, Iran: The Neolithic settlement, ed. M. Voigt. (Monograph 50.) Philadelphia (PA): University Museum, 369-422.

Moradi, B., M. Mashkour, H. Eghbal, et al., 2016. A short account on Kelek Asad Morad, a Pre-Pottery Neolithic Site in Pol-e Dokhtar, Luristan, in The Neolithic of the Iranian Plateau: Recent research, eds. K. Roustaei \& M. Mashkour. Berlin: ex oriente, 1-14.

Munro, N.D. \& L. Grosman, 2010. Early evidence (ca. 12,000 B.P.) for feasting at a burial cave in Israel. Proceedings of the National Academy of Science 107 (35), 15362-6.

Nishiaki, Y. \& H. Darabi, 2018. The earliest Neolithic lithic industries of the Central Zagros: new evidence from East Chia Sabz, Western Iran. Archaeological Research in Asia. https://doi.org/10.1016/j.ara.2018.02.002

Peasnall, B.L., 2000. The Round House Horizon along the Taurus-Zagros Arc: A Synthesis of Recent Excavations of Late Epipaleolithic and Early Aceramic Sites in Southeastern Anatolia and Northern Iraq. PhD dissertation, University of Pennsylvania.

Perkins, D., 1964. Prehistoric fauna from Shanidar, Iraq. Science 144(3626), 1565-6.

Peters, J., D. Helmer, A. von den Dreisch \& M. Seguí, 1999. Early animal husbandry in the northern Levant. Paléorient 25(2), 27-47.

Peters, J. \& C. Schmidt, 2004. Animals in the symbolic world of Pre-Pottery Neolithic Göbekli Tepe, south- eastern Turkey: a preliminary assessment. Anthropozoologica 39(1), 179-218.

Petone, P., S. Mattiolo \& L. Mattiolo, 1995. Body size and growth patterns in wild boars of Tuscany, central Italy. IBEX Journal of Mountain Ecology 3, 66-8.

Price, M.D., \& B.S. Arbuckle, 2013. Early pig management in the Zagros flanks: reanalysis of the fauna from Neolithic Jarmo, Northern Iraq. International Journal of Osteoarchaeology 25(4), 441-53.

Price, M.D. \& A. Evin, 2019. Long-term morphological changes and evolving human-pig relations in the northern Fertile Crescent from 11,000 to $2000 \mathrm{cal}$. BC. Archaeological and Anthropological Sciences 11 (1), 237-51.

Redding, R.W. \& M. Rosenberg, 1998. Ancestral pigs: a New (Guinea) model for pig domestication in the Middle East, in Ancestors for the Pigs, ed. S. Nelson. (MASCA Research Papers in Science and Archaeology 15.) Philadelphia (PA): University of Pennsylvania Museum of Archaeology and Anthropology, 65-76.

Reed, C.A., 1960. A review of the archaeological evidence on animal domestication in the Prehistoric Near East, in Prehistoric Investigations in Iraqi Kurdistan, eds. R.J. Braidwood \& B. Howe. Chicago (IL): University of Chicago Press, 119-45.

Riehl, S, M. Zeidi \& N. Conard, 2013. Emergence of agriculture in the foothills of the Zagros Mountains of Iran. Science 341, 65-7.

Rosenberg, M. \& M. Davis, 1992. Hallan Cemi Tepesi, an early aceramic Neolithic site in eastern Anatolia: some preliminary observations concerning material culture. Anatolica 18(1), 18.

Rosenberg, M., R.M. Nesbitt, R.W. Redding \& B. L. Peasnall, 1998. Hallan Çemi, pig husbandry, and post-Pleistocene adaptations along the Taurus-Zagros Arc (Turkey). Paléorient 24(1), 25-41.

Rosenberg, M., R.M. Nesbitt, R.W. Redding \& T.F. Strasser, 1995. Hallan Çemi Tepesi: some preliminary observations concerning Early Neolithic subsistence behaviors in Eastern Anatolia. Anatolica 21, 1-12.

Rowley-Conwy, P., 2018. Zooarchaeology and the elusive feast: from performance to aftermath. World Archaeology 50(2), 221-41.

Solecki, R.L., 1977. Predatory bird rituals at Zawi Chemi Shanidar. Sumer 33, 42-7.

Solecki, R.L., 1981. An Early Village Site at Zawi Chemi Shanidar. (Bibliotheca Mesopotamia 13.) Malibu (CA): Undena Publications.

Stampfli, H.R., 1983. The fauna of Jarmo with notes on animal bones from Matarrah, the Amuq, and Karim Shahir, Prehistoric Archaeology Along the Zagros Flanks, eds. L.S. Braidwood, R.J. Braidwood, B. Howe, C.A. Reed \& P.J. Watson. (University of Chicago Oriental Institute Publications 105.) Chicago (IL): Oriental Institute, 431-84.

Turnbull, P.F., 1983. The faunal remains from M'Lefaat, in Prehistoric Archaeology Along the Zagros Flanks, eds. L. S. Braidwood, R.J. Braidwood, B. Howe, C.A. Reed \& 
P.J. Watson. (University of Chicago Oriental Institute Publications 105.) Chicago (IL): Oriental Institute, 693-5.

Turnbull, P.F. \& C.A. Reed, 1974. The fauna from the terminal Pleistocene of Palegawra Cave, a Zarzian occupation site in Northeastern Iraq. Fieldiana 63, 81-146.

Twiss, K.C. 2008. Transformations in an early agricultural society: feasting in the southern Levantine Pre-Pottery Neolithic. Journal of Anthropological Archaeology 27, 418-42.

Zeder, M.A. 2008. Animal domestication in the Zagros: an update and directions for future research, in Archaeozoology of the Near East VIII: Proceedings of the 8th international symposium on the archaeozoology of southwestern Asia and adjacent areas, eds. E. Vila, L. Gourichon, A.M. Choyke \& H. Buitenhuis. Lyons: Maison de 1'Orient et de la Méditerranée, 243-78.

Zeder, M.A., 2011. The origins of agriculture in the Near East. Current Anthropology 52, S221-S235.

Zeder, M.A. \& M.D. Spitzer, 2016. New insights into broad spectrum communities of the Early Holocene Near East: the birds of Hallan Çemi. Quaternary Science Reviews 151, 14059.

\section{Author biographies}

Pernille Bangsgaard is Assistant Professor at the Natural History Museum of Denmark and coordinator of ArchaeoScience which facilitates natural science analysis to Danish Archaeological Museums. She holds a PhD in Near Eastern Archaeology, with a specialisation in Zooarchaeology. The PhD thesis focused on faunal deposit practices at C-Group and Pan-grave Cemeteries. Her research interest is the relationships between human societies and the animals they kept, bred and ate, ranging from an Early Neolithic ritual deposit of wild boar skulls to how meat was consumed in an Early Islamic town. She works on projects in the Middle East, northeast Africa and Denmark.

Lisa Yeomans is a zooarchaeologist and field archaeologist. She is a post-doctoral researcher at the University of Copenhagen and received her $\mathrm{PhD}$ from University College London on integrating zooarchaeological and historical evidence for the industries processing animal carcasses in Post-Medieval London. Her research is now focused on the use of animals in Southwest Asia with a particular interest in fish exploitation as well as the changing use of animals as a result of environmental and hunting strategy shifts in the Epipalaeolithic and Early Neolithic.

Hojjat Darabi is Assistant Professor of prehistoric archaeology at Razi University, Iran, with a particular interest in Neolithic archaeology. He has directed excavations at several Iranian Neolithic sites including East Chia Sabz, Mahtaj and Ali Kosh and is also co-directing the current Iranian-Danish project to investigate Neolithisation process of the central Zagros which has so far offered revisiting excavations at sites of Asiab and Ganj Dareh. In addition to various articles on the Neolithic period of western and southwestern Iran, Hojjat Darabi has also authored a book entitled An Introduction to the Neolithic Revolution of the Central Zagros, Iran.

Kristian Murphy Gregersen is the collection manager for the Quaternary Collections, Natural History Museum of Denmark. He has bachelor and master degrees in conservation from the Royal Danish Academy of Fine Arts, School of Conservation.

Jesper Olsen is Associate Professor at the Department of Physics and Astronomy.

Tobias Richter is an Associate Professor for the Prehistory of Western Asia at the University of Copenhagen. He read archaeology at the University of Wales Lampeter and University College London. He directs the Shubayqa Archaeological Project, which investigates the transition from Epipalaeolithic to Neolithic societies in northeast Jordan, and is co-director of the Tracking Cultural and Environmental Change project.

Peder Mortensen is an Adjunct Professor in Near Eastern Studies at the Department of Cross-Cultural and Regional Studies, University of Copenhagen. In 1961 he was appointed as Assistant Keeper of Near Eastern and Greek Prehistory at the National Museum in Copenhagen before moving to the University of Aarhus as Lecturer in Near Eastern Prehistory in 1967. He was Director of Moesgaard Museum 1982-95 and the first Director of Danish Institute in Damascus from 1996 to 2001. He has published numerous books and papers on archaeological excavations in Bahrain, Iran, Iraq, Jordan, Syria and Turkey. 